\title{
The Molecular Hallmarks of the Serrated Pathway in Colorectal Cancer
}

\author{
Fatima Domenica Elisa De Palma ${ }^{1,2, *}$, Valeria D'Argenio ${ }^{1,2} \mathbb{D}$, Jonathan Pol ${ }^{3,4} \mathbb{D}^{\text {, }}$ \\ Guido Kroemer ${ }^{3,4,5,6}$, Maria Chiara Maiuri ${ }^{3,4}$ and Francesco Salvatore ${ }^{1,2, *(D)}$ \\ 1 CEINGE-Biotecnologie Avanzate s.c.ar.l., 80145 Naples, Italy \\ 2 Department of Molecular Medicine and Medical Biotechnologies, University of Naples Federico II, \\ 80131 Naples, Italy \\ 3 Team of Metabolism, Cancer \& Immunity, Centre de Recherche des Cordeliers, UMRS1138, \\ Université Paris Descartes, Sorbonne Université, Université Paris Diderot, 75006 Paris, France \\ 4 Metabolomics and Cell Biology Platforms, Gustave Roussy Cancer Campus, 94805 Villejuif, France \\ 5 Pôle de Biologie, Hôpital Européen Georges Pompidou, Assistance Publique-Hôpitaux de Paris, \\ 75015 Paris, France \\ 6 Department of Women's and Children's Health, Karolinska Institute, Karolinska University Hospital, \\ 17176 Stockholm, Sweden \\ * Correspondence: depalma@ceinge.unina.it (F.D.E.D.P.); salvator@unina.it (F.S.); \\ Tel.: +39-334-817-6281 (F.D.E.D.P.)
}

Received: 11 June 2019; Accepted: 19 July 2019; Published: 20 July 2019

\begin{abstract}
Colorectal cancer (CRC) is a leading cause of cancer death worldwide. It includes different subtypes that differ in their clinical and prognostic features. In the past decade, in addition to the conventional adenoma-carcinoma model, an alternative multistep mechanism of carcinogenesis, namely the "serrated pathway", has been described. Approximately, 15 to 30\% of all CRCs arise from neoplastic serrated polyps, a heterogeneous group of lesions that are histologically classified into three morphologic categories: hyperplastic polyps, sessile serrated adenomas/polyps, and the traditional serrated adenomas/polyps. Serrated polyps are characterized by genetic (BRAF or KRAS mutations) and epigenetic (CPG island methylator phenotype (CIMP)) alterations that cooperate to initiate and drive malignant transformation from normal colon mucosa to polyps, and then to CRC. The high heterogeneity of the serrated lesions renders their diagnostic and pathological interpretation difficult. Hence, novel genetic and epigenetic biomarkers are required for better classification and management of CRCs. To date, several molecular alterations have been associated with the serrated polyp-CRC sequence. In addition, the gut microbiota is emerging as a contributor to/modulator of the serrated pathway. This review summarizes the state of the art of the genetic, epigenetic and microbiota signatures associated with serrated CRCs, together with their clinical implications.
\end{abstract}

Keywords: colorectal cancer; serrated pathway; serrated lesions; serrated polyp; CIMP; DNA methylation; MSI; CIN; serrated adenocarcinoma; gut microbiota

\section{Introduction}

The Conventional Model of Colorectal Carcinogenesis and the "Serrated" Pathway

Colorectal cancer is a multifactorial and heterogeneous disease [1]. Most CRCs (75\%) are sporadic, whereas about $20 \%$ of CRC patients report a family history of the disease. Finally, 3-5\% of CRCs are hereditary, with subjects bearing highly penetrant germline mutations that are associated with well-defined cancer-predisposing syndromes such as the hereditary nonpolyposis colorectal cancer 
(HNPCC), best known as Lynch syndrome (1-3\%), or the familial adenomatous polyposis (FAP) $(<1 \%)$, or again the hamartomatous polyposis syndrome, which displays the lowest incidence $(<0.1 \%)$ [2].

CRC pathogenesis is due to the progressive accumulation of genetic and epigenetic alterations, some of which being responsible for activating oncogenes or inactivating oncosuppressor genes, that are able to drive the malignant evolution from normal epithelium through early neoplastic lesions (aberrant crypt foci, adenomas, and serrated adenomas) to CRC [3,4]. Such malignant transformation requires up to 15 years, depending on the characteristics of the lesion and on other independent risk factors such as gender, body weight, body mass index, physical inactivity [5].

Neoplastic transformation affecting the colon epithelium is characterized by two distinct morphological pathways of carcinogenesis, namely the conventional and the alternative/serrated neoplasia pathways, each one being defined by specific genetic and epigenetic alterations, typical clinical and histological features and leading to different phenotypes [6-8].

The conventional model, the so-called adenoma-carcinoma sequence, is histologically homogeneous and morphologically characterized the adenoma, including tubular or tubulovillous adenoma, as a precursor lesion [1]. The adenoma-carcinoma sequence is a multistep mutational pathway, in which each histological alteration is the consequence of a molecular dysregulation [9-12]. At the molecular level, this model recognizes a heterogeneous background, based on two mechanisms of tumorigenesis: (i) chromosomal instability (CIN) or (ii) microsatellite instability (MSI) [13-16] (Figure 1).

CIN - Chromosomal Instability pathway

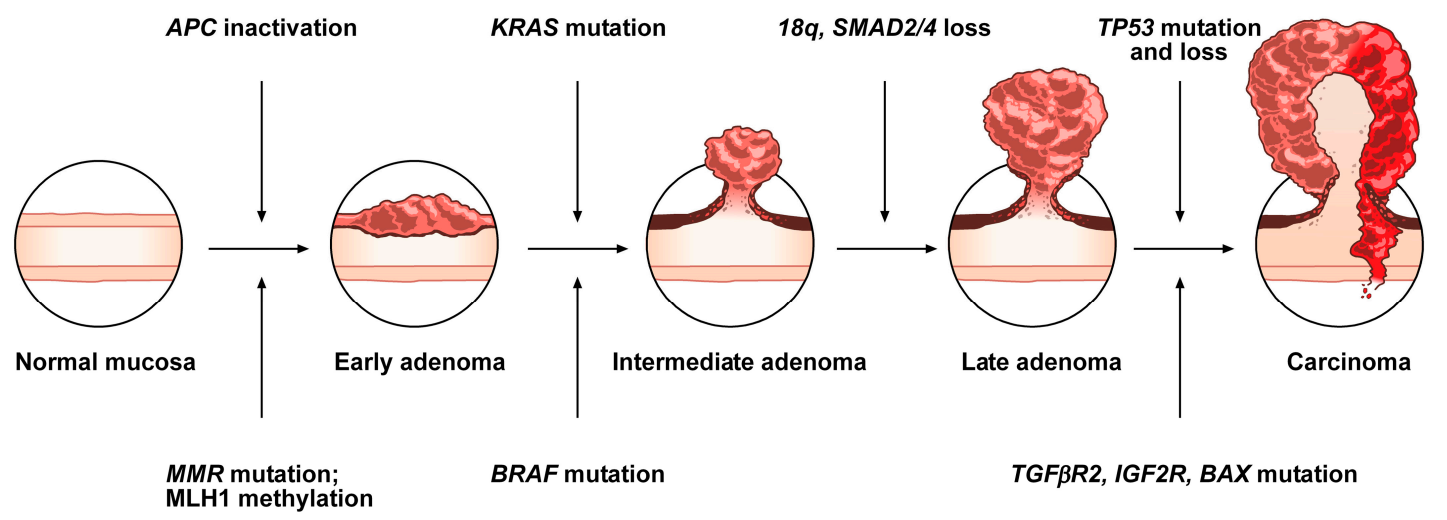

MSI - Microsatellite Instability pathway

Figure 1. Conventional adenoma-to-carcinoma sequence. The chromosomal instability (CIN) pathway begins with bi-allelic mutations in the tumor suppressor gene APC within the normal colonic mucosa. The latter progressively differentiate into adenocarcinoma upon acquisition of additional mutations in the genes KRAS, SMAD4, and TP53, with consequent dysregulation of the Wnt/ $\beta$-catenin, MAPK, PI3K and TGF- $\beta$ signaling pathways. Alternatively, the MSI pathway involves an initial alteration of the Wnt signaling that leads to the formation of an early adenoma. Then, $B R A F$ mutation followed by alterations of the genes TGFBR2, IGF2R, and BAX, participate in the progression toward the intermediate and late stages of carcinogenesis.

CIN represents the most prevalent form of genomic instability. It is detected in $85 \%$ of sporadic CRCs and is frequently observed in distal, rather than proximal, colon cancer sites $[15,16]$. CIN consists of a gain or loss of all or part of chromosome(s), and is usually associated with mutations in proto-oncogenes or tumor suppressor genes, such as KRAS or APC, respectively [13,16].

MSI occurs in about $15 \%$ of CRCs, predicts a favorable outcome in CRC and can also be detected in the serrated pathway [15,17-19]. This genomic instability does not affect chromosomal integrity but consists of an accumulation of insertions/deletions of short nucleotide repeats (microsatellites) that 
is consecutive to hereditary $(5 \%)$ or sporadic $(10 \%)$ alterations in genes involved in DNA mismatch repair (MMR) [14,15].

Although MSI, according to the National Cancer Institute, is frequently determined using a panel of five markers (BAT25, BAT26, D2S123, D5346, and D17S250), a variety of commercially available panels are currently used in most laboratories [20]. Depending on the number of microsatellites associated with these markers, tumors have been subclassified into: (i) high, labeled "MSI", (ii) low, labeled "MSI-L" or (iii) stable, labeled "MSS" [21]. MSI-L tumors have been regrouped with MSS tumors, due to low differences in their clinicopathological characteristics or in most of their molecular features [22].

Approximately, $3-15 \%$ of all CRCs are represented by sporadic forms with MSI [21,23]. Several studies have demonstrated that epigenetic hypermethylation ( $80 \%$ of MSI CRCs), and the consequent silencing and inactivation of the gene $M L H 1$, is the event that triggers malignant transformation and determines a high rate of MSI [21,23]. Moreover, mutations in MMR genes (20\% of MSI CRCs) can also determine MSI tumors, associated with HNPCC (3\% of CRCs) [21,23]. HNPCC is an autosomal dominant disease due to germline mutations in some MMR genes (e.g., MSH2, MLH1, MSH6, PMS2, and PMS1), causing consequent inactivation of the DNA repair system and the accumulation of mutated microsatellites [24]. In addition, germline deletions in the 3' end of EPCAM result in epigenetic inactivation of the adjacent gene $\mathrm{MSH} 2$ and represent another mutational mechanism responsible for HNPCC (1-3\% of HNPCC patients) [25]. HNPCC is not characterized by MLH1 hypermethylation. Thus, MSI analysis, in addition to MLH1 evaluation and BRAF mutation analysis, is currently one of the first steps for the diagnosis of this disease [24,26].

In contrast to the conventional adenoma-carcinoma pathway, an alternative pathway, featured by the presence of serrated adenomas/polyps as precursor lesions, has been documented over the last 10 years [21,27-31]. It has been estimated that 15 to $30 \%$ of all CRCs arise from early neoplastic serrated lesions. These lesions, that are histologically characterized by a "serrated" (or saw-toothed) appearance of the epithelial glandular crypts within the precursor polyps, have long been considered innocuous [31-34]. Nevertheless, serrated lesions are among the main causes of the "interval" CRCs and are associated with synchronous and metachronous advanced colorectal neoplasia $[35,36]$.

At the molecular level, serrated colorectal lesions rarely present truncating APC mutations. The majority of CRCs arising from serrated lesions carry $B R A F$ mutations (whose prevalence varies among the different serrated subtypes), while KRAS mutations remain less frequent. They are also associated with two pathways, namely MSI and the CpG island methylator phenotype (CIMP), which are involved in genomic instability; the latter being considered as the major mechanism that drives the serrated pathway toward CRC [37,38].

Although the role of APC mutations, and the subsequent aberrant activation of the WNT pathway, is fully understood in the conventional adenoma-carcinoma sequence, its role in the serrated pathway remains unclear. To address this issue, the mutational landscape of $A P C$ in serrated precursors and $B R A F$ mutant cancers has been recently explored [39]. In the cited study, even if the WNT pathway was notably activated in dysplastic serrated lesions and $B R A F$ mutant cancers, it was not due to truncating $A P C$ mutations, suggesting the existence of alternative mechanisms of activation of the WNT signaling. Moreover, the role of missense APC mutations, which are relatively frequent in serrated lesions and $B R A F$ mutant cancers with MSI, should be further investigated in the serrated pathway.

Overall, CRCs have been classified into five molecular subtypes based on their MSI and CIMP status, among which the three following signatures describe serrated lesions [21]:

- $\quad$ CIMP-H, MLH1 methylated, MSI, BRAF mutated lesions, known as sporadic MSI;

- $\quad$ CIMP-H, MLH1 partially methylated, MSS, BRAF mutated lesions;

- $\quad$ CIMP-L, MGMT methylated, MSS, KRAS mutated lesions.

However, alternative molecular classifications have been proposed based on recent findings, such as those defined by the CRC Subtyping Consortium (CRCSC) or by Fennell et al. [40-42]. 
The heterogeneity of serrated lesions and the presence of morphological features shared with different subtypes, make difficult the accurate CRC classification during the diagnostic process and also the physiopathological interpretation of the observed lesions. In addition, serrated lesions with a distinctive endoscopic appearance are more difficult to detect compared to conventional lesions. In fact, detection of serrated lesions, particularly those located in the proximal colon, is difficult and endoscopist-dependent $[43,44]$. Therefore, characterization of molecular markers specific for each CRC subtype may improve the identification of CRCs arising from this alternative pathway, and consequently support the diagnostic process as well as the clinical decision-making.

This review will focus on the genetic and epigenetic features involved in the development of the serrated lesion patterns and their relationship with CRC development. In particular, since the methylation status has emerged as a relevant biomarker for CRC classification/prognostic evaluation and is also involved in the progression of serrated lesions toward carcinoma, we will first describe the methylation alterations related to CRCs. Then, the genetic and epigenetic alterations related to serrated precursor lesions and to the serrated pathway will be detailed, with particular attention on one of the endpoints of the serrated pathway, namely the serrated adenocarcinoma.

We will also report the recently discovered superficially serrated adenomas subtype as well as the association between gut microbiota and the serrated pathway. Finally, the clinical implications of the serrated colorectal pathway will be discussed.

\section{Histopathological and Endoscopic Features of Serrated Colorectal Lesions}

Serrated neoplasia of the colorectum represents one of the CRC subtypes [45]. They are histologically classified by the World Health Organization (WHO) into three morphological categories: (i) hyperplastic polyp (HP), (ii) sessile serrated adenoma/polyp (SSA/P) with or without cytological dysplasia (SSAD), and (iii) the traditional serrated adenoma/polyp (TSA) (Figure 2) (Table 1) [46]. The serrated subtypes, identified by their cytological characteristics and lesion area, have a distinct endoscopic appearance, share some histological features, and are unique at the biological and molecular levels $[34,47]$.

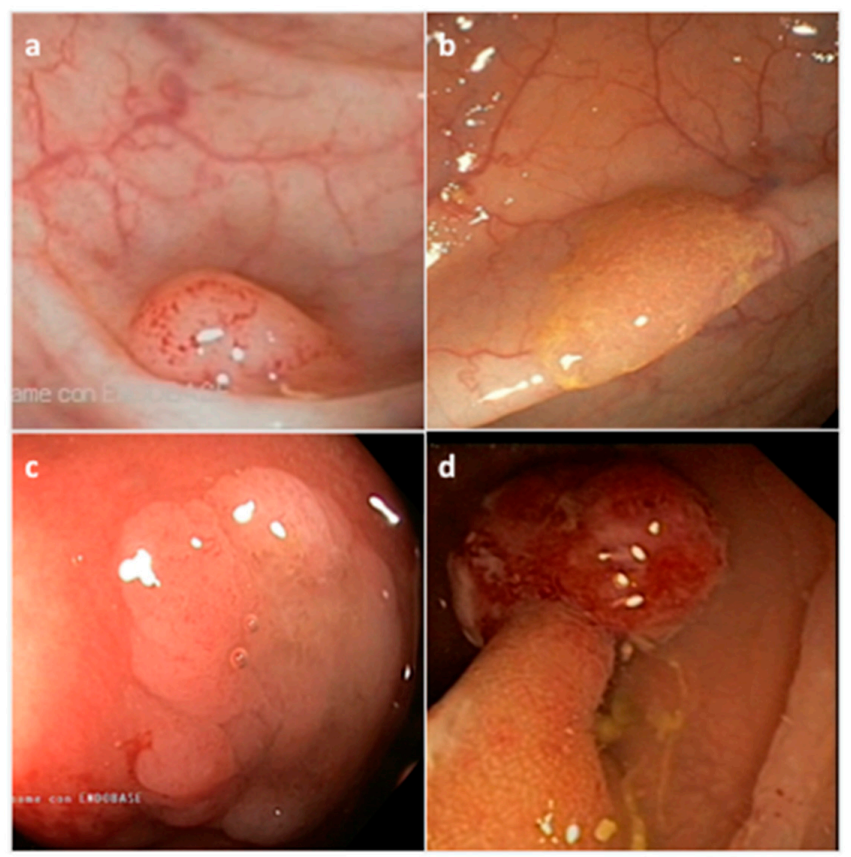

Figure 2. Representative endoscopic appearance of serrated lesions of the colorectum. (a) Hyperplastic polyp; (b) Sessile serrated adenoma/polyp; (c) Sessile serrated adenoma/polyp with dysplasia; (d) Traditional serrated adenoma. (Courtesy of Prof. Dr. Giovanni D. De Palma, University of Naples Federico II, Naples, Italy). 
Table 1. Morphologic categories and features of serrated colorectal lesions.

\begin{tabular}{llllll}
\hline Histological Classification & Frequency (\%) * & Location & Shape & Mucin Type & Size \\
\hline Hyperplastic polyp (HP) & $80-90 \%$ & Distal & Sessile, Flat & Variable & $<5 \mathrm{~mm}$ \\
Microvesicular HP (MVHP) & $60 \%$ & Distal & Sessile & Microvesicular & $<5 \mathrm{~mm}$ \\
Goblet cell HP (GCHP) & $30 \%$ & Distal & Sessile & Goblet cells & $<5 \mathrm{~mm}$ \\
Mucin poor HP (MPHP) & $10 \%$ & Distal & Sessile & Poor & $<5 \mathrm{~mm}$ \\
Sessile serrated adenoma/polyp (SSA/P) & $15-20 \%$ & Proximal & Sessile/Flat & Microvesicular & $>5 \mathrm{~mm}$ \\
Traditional serrated polyp (TSA) & $1-6 \%$ & Distal & Sessile/Pedunculated & Not present & $>5 \mathrm{~mm}$ \\
\hline
\end{tabular}

${ }^{*}$ Frequency of all serrated polyps.

HP precursor lesions are the most frequent polyps (80-90\%) and mostly remain benign (Figure 2a) (Table 1) [48]. HPs may be flat or sessile, are preferentially located in the distal colon, show a smaller size $(<5 \mathrm{~mm})$ than other subtypes, and remain hardly detectable by endoscopic exam. Based on the epithelial mucin content, HP lesions can be histologically subclassified into microvesicular HP (MVHP), goblet cell HP (GCHP), and mucin poor HP (MPHP) polyps (Table 1) [28,30,34]. Although the frequency of each HP subtypes is variable, MVHPs are the most common, while MPHPs are the rarest form of HPs [49,50].

SSA/Ps, which account for 15 to $20 \%$ of all serrated polyps, especially develop in the proximal colon, are pale lesions that can be either sessile or flat, with a variable size usually larger than $5 \mathrm{~mm}$ in diameter (Figure 2b) (Table 1) [48,51,52]. SSA/Ps can develop either as primary tumors or evolve from hyperplastic polyps. SSA/Ps lesions cannot be easily distinguished from MVHPs, however, MVHPs larger than $10 \mathrm{~mm}$ in diameter can be considered clinically equivalent to SSA/Ps. Additionally, SSA/Ps can be subclassified according to the absence or presence of dysplasia (SSAD); the latter being detected in about $0.20 \%$ of all serrated lesions (Figure 2c) [51]. Overall, by combining both serrated and dysplastic features, SSADs consist of advanced lesions that usually evolve rapidly toward carcinoma.

TSA lesions are the rarest form of colorectal serrated polyps (1-6\%) (Figure 2d) (Table 1) [34,48]. TSAs, that arise either from HPs or SSA/Ps, are precancerous sessile or, more often, pedunculated polypoid lesions, which preferentially develop in the distal colon and rectum, and show a larger size ( $>5 \mathrm{~mm}$ ) than HPs [50]. A less aggressive variant form of TSA is the filiform serrated adenoma [53]. TSA can also be subclassified according to the presence of dysplasia that can be of two types: the well-known "adenomatous dysplasia" and the less frequently observed "serrated dysplasia", which is related to the serrated pathway. The latter can be graded as low- or high-grade dysplasia depending on the absence or presence of cytological and architectural atypia, respectively. Recently, it has also been evidenced that TSA can co-exist with other lesions such as HPs, SSA/Ps and tubulovillous adenomas [54]. Usually, only TSA with serrated dysplasia develops into invasive carcinomas.

\section{CpG island Methylator Phenotype, an Epigenetic Signature of Serrated Colorectal Lesions}

Methylation is one of the epigenetic mechanisms that regulate gene expression [55,56]. Precisely, it consists of biochemical modification of the DNA that is catalyzed by DNA methyltransferases and results in the covalent addition of a methyl group $\left(\mathrm{CH}_{3}\right)$ to the carbon 5 of the cytosine ring of $\mathrm{CpG}$ islands (Cytosine-Guanine dinucleotide group) located in gene promoter regions [56].

DNA methylation (mDNA) is a regulatory mechanism used by cells to silence the expression of a target gene, such as a tumor suppressor gene. In particular, when a CpG site is methylated within the promoter region of a gene, its transcription is inhibited. Aberrant DNA hyper/down-methylation is involved in several diseases, including cancer [57]. Interestingly, assessing the methylation status of specific genes could be useful in clinical practice. Indeed, it could represent a biomarker for the detection or monitoring of specific diseases such as CRC, and more particularly of the serrated lesions that are associated with a CIMP signature [58-60]. For instance, a recent study reported on a positive correlation between CIMP and older age in SSA/Ps, indicating a lower risk of developing a malignancy in young patients [61].

It has been estimated that 20-30\% of all CRCs harbor the CIMP phenotype [62-64]. In serrated lesions, although the CPG island methylation can occur in crypt foci and small HPs, the normal 
mucosa of patients affected by hyperplastic polyposis (HPP) or CRC has demonstrated promoter hypermethylation in some specific genes, accompanied with genetic predisposition to such epigenetic event $[22,65,66]$.

CIMP represents a distinct phenotype in CRC, with specific clinical, pathological and molecular features [64,67]. The origin of CIMP, including its association with $B R A F$ mutation remains controversial. Several hypotheses, such as the implication of $B R A F$ or $M A F G$, have been explored $[68,69]$. Using a mouse model of colon derived-organoids, Tao et al. have recently demonstrated that aging-like spontaneous methylation of multiple genes produces a cell that avoid BRAF-induced senescence, and predisposes colon cells to oncogene-driven carcinogenesis [70].

CIMP can be graded as low (CIMP-L), high (CIMP-H) or negative (CIMP-0), depending on the degree of simultaneous hypermethylations occurring in several $\mathrm{CpG}$ islands located near the promoter region of tumor suppressor genes (Table 2) [71,72].

Table 2. Characteristics of $\mathrm{CpG}$ island methylator phenotype (CIMP) subtypes bearing serrated colorectal lesions.

\begin{tabular}{llll}
\hline CIMP Phenotype & CIMP-0 & CIMP-L & CIMP-H \\
\hline Location & Distal colon & Proximal colon & Proximal colon \\
Gender & no gender bias & Male & Female \\
Pathway & Conventional adenoma & Serrated or Conventional & Serrated adenoma \\
Gene mutations & TP53 mutations & KRAS, TP53 mutations & BRAF mutations \\
Epigenetic alterations & no MLH1 methylation & no MLH1 methylation & MLH1 hypermethylation \\
MSI rate & MSS & MSS & MSI \\
CIN association & positive & positive & negative \\
Prognosis & Variable & High & Poor \\
\hline
\end{tabular}

CIMP-H, which is preferentially localized in the proximal colon, occurs more frequently in females and in older age, and shows the poorest prognosis compared to CIMP-L [62,73]. At the molecular level, CIMP-H is often a MSI tumor and is featured by the inactivation of WNT/ $\beta$-catenin pathway, high $B R A F$ and low TP53 mutation rates. In comparison, CIMP-L is associated with KRAS mutations while CIMP-0 is characterized by frequent mutations in TP53 (Table 2) [62,74].

Although the categorization and the cut-off between the CIMP high and low phenotypes have been modified several times over the last years, there are currently two panels of genes used to define the CIMP phenotype. The first one was described by Toyota and considers $p 16, h M L H 1$, MINT1, MINT2, and MINT31, while the second panel has been described by Weisenberger and takes into consideration CACNA1G, IGF2, NEUROG1, RUNX3, and SOCS1. These panels allow to verify the transcriptional inactivation of the genes mentioned and involved in the carcinogenetic development $[75,76]$.

As described above, the hypermethylation status of the genes listed in the CIMP panels can be used as a biomarker for prognosis, prediction, diagnosis and response to chemotherapy of CRC. For instance, evaluation of the methylation status of the MLH1 promoter is nowadays added to genetic testing for the hereditary Lynch syndrome, usually MLH1 negative [24].

Another epigenetic marker is $\mathrm{O}(6)$-methylguanine-DNA methyltransferase (MGMT) [21,77]. Hypermethylation of the MGMT promoter is preferentially associated with KRAS mutations, CIMP-L, MSS phenotype due to the overloading of the DNA mismatch repair system. The methylation and the loss of MGMT are highly variable among the CRC subtypes, occurring usually in $22 \%$ of HPs, $25 \%$ SSA/Ps, $16-22 \%$ serrated adenoma, and $50 \%$ of serrated adenocarcinoma, but is less frequently associated with HNPCC (6\%) [77].

Different methylome-based studies, as the recent one of Parker et al., have identified candidate markers for DNA methylation in serrated CRC, notably for the pre-colonoscopy detection of precancerous lesions [78]. These biomarkers of precancerous serrated lesions include BMP3, NDRG4, ANXA10 and are analyzed through stool DNA tests. They allow distinguishing between SSA/Ps and conventional adenomas $[79,80]$. 
Genome-scale mDNA studies have also been applied to better characterize the DNA methylation subtypes in CRC. In light of the identification of four DNA methylation-based subgroups of CRC, five clinically and molecularly distinct CIMP subtypes in CRC (CIMP-H1, CIMP-H2, CIMP-L1, CIMP-L2 and CIMP-neg), based on a comprehensive methylome-based study and validated in a larger cohort of CRC data from TCGA, have also been identified recently $[42,81]$. In this new scenario, the major difference between this latter and the current CIMP classification is the dichotomization between CIMP-H1 and -H2 cancers. While CIMP-H1s are characterized by female gender preponderance, and proximal colon location for BRAF mutated tumors, CIMP-H2s are preferentially located in distal colon and frequently harbor KRAS mutations.

At present, there are several gene methylation analysis methods to define the CIMP-CRC profile, such as the non-quantitative methylation-specific PCR (MSP) technique or the high-throughput quantitative methylation PCR MethyLight assay. In addition, pyrosequencing, InfiniumMethylation bead array, MassARRAY, methylation-sensitive high-resolution melting (MS-HRM), next generation sequencing (Methyl-Seq) and combined bisulfite restriction analysis (COBRA) methods can also be used.

Although the comprehension of the epigenome landscape needs to be extended, the identification of specific epigenetic alterations driving tumor progression has become crucial to better classify the heterogeneous molecular subtypes of CRC. Ultimately, it will facilitate the development of innovative epigenome-based personalized medicine strategies.

\section{Molecular Features of the Serrated Colorectal Precursor Lesions}

\subsection{Hyperplastic Polyps}

As described above, hyperplastic polyps can be histologically subclassified into MPHP, GCHP and MVHP lesions (Table 1). The endoscopic diagnosis between these subtypes, and furthermore between HPs and SSA/Ps, is difficult and may be supported by the detection of specific biomarkers.

MPHP is the rarest form of HP and is not well described; in fact, to date, it has only been associated with CIMP-H (Table 3). MVHP and GCHP are the most common HP subtypes. At the molecular level, MVHP is particularly characterized by BRAF V600E mutation and CIMP-H (Table 3); for that reason, it is considered a precursor of SSA/Ps [17,82].

Table 3. Molecular profile of serrated colorectal lesions.

\begin{tabular}{lllll}
\hline Serrated Lesion & BRAF/KRAS Status & CIMP Rate & Gene Methylation & MSI Rate \\
\hline HP & BRAF mutated & CIMP-H & MLH1 not methylated & MSS \\
MPHP * & controversial & CIMP-H & controversial & controversial \\
GCHP * & KRAS mutated & CIMP-L & MLH1 not methylated & MSS \\
MVHP * & $B R A F$ mutated & CIMP-H & MLH1 not methylated & MSS \\
SSA/P & BRAF mutated & CIMP-H & MLH1 not methylated & MSS \\
SSAD & BRAF mutated & CIMP-H & MLH1 hypermethylated & MSI \\
TSA & KRAS/BRAF mutated or neither & CIMP-L/-H & MLH1 not methylated & MSS \\
TSA HGD & KRAS mutated & CIMP-L & MGMT hypermethylated & MSS \\
\hline
\end{tabular}

* MPHP, GCHP, MVHP are HP subtypes.

GCHP is linked to KRAS mutations (often missense substitutions at glycine codons 12 or 13) and CIMP-L (Table 3) $[19,83]$. Mutations in BRAF or KRAS, that rarely coexist in CRC, constitutively activate the MAPK signaling pathway, which is involved in the regulation of several cellular processes, and inhibit the apoptosis mechanism, thus supporting tumor cell proliferation.

To shed light on other molecular features of HP lesions, early markers of potentially malignant serrated precursor lesions have been identified, such as MUC5AC [84,85]. MVHP and SSA/P lesions present an hypomethylated MUC5AC when compared to GCHPs. Interestingly, this gene hypomethylation occurs early in the serrated pathway, gradually increasing from MVHP to SSA and SSAD, and is particularly related to lesions with BRAF mutations, CIMP-H and MSI. Thus, 
the epigenetic alteration of MUC5AC could be a potential marker to evaluate the malignant evolution of serrated precursor polyps.

\subsection{Sessile Serrated Adenoma/Polyps}

At the molecular level, SSA/Ps are mainly characterized by BRAF mutations, MSS, CIMP-H and unmethylated MLH1 (Table 3) [17,86]. Other molecular characteristics of sessile serrated lesions, as well as a subtype-specific gene signature, have been explored and, in some cases, identified based on epigenetic and transcriptomic approaches. An example is the recent molecular characterization of SSA/Ps in a large African American cohort, in which the over-expression of FSCN1 and TRNP1 seemed to segregate with race [87].

The formation of SSA/Ps has been associated with the tumor suppressor gene SLIT2, who is down-expressed in SSA/Ps compared to TSAs/adenomas/normal tissues as a result of promoter hypermethylation and loss of heterozygosity [88]. The high rate of SFRP4 methylation in SSA/P compared to the corresponding adenoma series has also been evidenced [86]. CTSE, TFF1 and ANXA10 were identified as potential clinical markers of SSA/P lesions [89-91]. In particular, ANXA10 expression levels significantly increased at the gene and protein levels in SSA/Ps in comparison to MVHPs [90,92]. Hes-1, a downstream target of the Notch signaling pathway which involved in intestinal development, has also been described as a SSA/P-specific biomarker due to its immunohistochemical (IHC) loss of expression in SSA/Ps compared to HPs or normal colonic mucosa [93].

In a large-scale study, differentially expressed genes and immunohistochemical markers were also identified when comparing SSA/Ps to controls [94]. In particular, among the 1294 genes identified, VSIG1 and MUC17, were uniquely and significantly increased in SSA/Ps with respect to controls/HPs/adenomas, thus evidencing a molecular signature specific of the polyps and the involvement of different molecular pathways across distinct CRC lesions.

Recently, a platform-independent approach was adopted in order to differentiate SSA/P from HP lesions [95]. SSA/Ps have been characterized by a specific molecular profile of up-/down-regulated genes involved in the inflammatory process, immune response, epithelial-mesenchymal transition (EMT), extracellular matrix (ECM) interaction, cell migration and cell growth. This profile defines the malignant potential of SSA/P lesions and allow to distinguish them from HPs.

As for MVHP polyps, SSA/P immunohistochemically expresses MUC2, MUC5AC and MUC6 [84,96]. The role of MUC6 was evaluated in SSA/Ps lesions and is controversial [84]. Nevertheless, MUC6 was assessed to be a supportive immunohistochemical marker to differentiate SSA/Ps from TSAs $[97,98]$.

\subsection{Sessile Serrated Adenoma/Polyps with Dysplasia}

The main molecular characteristics found in SSADs are BRAF mutations, a nuclear $\beta$-catenin accumulation, CIMP-H and MSI as a consequence of MLH1 gene silencing due to promoter hypermethylation (Table 3) [99]. Although the loss of MLH1 expression is related to the development of dysplasia, MLH1 inactivation can also be detected in SSA/P non-dysplastic crypts, indicating the putative biomarker role of $M L H 1$ in predicting dysplastic progression of these polyps [100].

Moreover, it has been demonstrated that SSAD lesions can be also associated with MSI, harboring different genetic alterations [99]. In particular, MSI lesions are characterized by a high mutational rate of FBXW7 and the loss of MLH1 expression, while MSSs display TP53 mutations without FBXW7 mutations. Thus, FBXW7 alterations can be correlated to the progression of MSI serrated lesions in CRC. 
SSAD polyps, and particularly the progression of SSA/P lesions toward dysplasia, can also be characterized by alterations in WNT signaling-associated genes like protein-truncating mutations of RNF43, APC, ZNRF3 and the hypermethylation of AXIN2 and MCC [99,101-103]. Furthermore, frameshift mutations in RNF43 are frequently present in patients with MLH1-deficient SSA/P with dysplasia [101].

Genetic variants of DNA-regulatory elements, such as single nucleotide polymorphisms (SNPs), can influence gene expression and be associated with cancer risk. An example is the well-known CRC-associated rs1800734, or MLH1-93G>A, which can be detected in the promoter region of MLH1. This SNP enhances DCLK3 expression which in turn promotes CRC development [104]. MLH1-93 G/a polymorphism has been significantly associated with MLH1 hypermethylation in SSAD lesions compared to TSAs, and represents a putative risk factor for MLH1 promoter methylation [105].

\subsection{Traditional Serrated Adenoma/Polyps with and without Dysplasia}

TSA is an enigmatic subtype due to its heterogeneous molecular features $[54,106]$. TSAs can harbor KRAS or BRAF mutations, or neither, and can be CIMP-low or high, and MSS (Table 3) [107]. In contrast with SSA/Ps, TSA lesions do not show MLH1 promoter hypermethylation but can present MGMT hypermethylation (Table 3) [108]. Evaluation of the mutational status of WNT genes in TSA lesions has identified precursor- and TSA-specific alterations that elucidate the mechanism involved in the genetic transition from precursor polyps to TSAs [109]. PTPRK-RSPO3 fusion and mutations in PTEN, RNF43, APC, or CTNNB1 are genetic features of TSAs [110,111].

Several epigenetic biomarkers have also been associated with TSA. An example is SMOC1 which is down-expressed, due to methylations in its promoter region, in TSAs as compared to SSA/Ps [112]. In particular, SMOC1 methylation increases during TSA development and has been correlated with KRAS mutation and CIMP-L. In addition, low expression of the SMOC1 protein in TSA can be verified by IHC assay, supporting its exploitation as a TSA-specific diagnostic biomarker.

The transition of TSAs toward dysplasia is characterized by nuclear $\beta$-catenin accumulation, TP53 mutation and $p 16$ inactivation, as detailed below [21]. TSA-HGDs are usually characterized by CIMP-H, BRAF mutations and MSS (Table 3). The high rate of differentially methylated region in the promoter P0 of IGF2 gene (IGF2 DMR0) and hypomethylation of LINE-1 are two epigenetic biomarkers of TSA-HGD [113]. LINE-1 hypomethylation in CRC has been associated with early age onset and family history of CRC. In several studies, LINE-1 hypomethylation has been inversely correlated with MSI and CIMP-H phenotypes. Interestingly, the methylation level of LINE-1 has recently been assessed from plasma-circulating cell-free DNA, thus comforting a putative role as a preventive biomarker in CRC $[114,115]$.

\section{Serrated Adenoma to Carcinoma Sequence: Initiation and Progression}

The colorectal carcinogenetic mechanisms that drive malignant transformation from the normal colon mucosa to serrated polyp, then to carcinoma can be distinguished in traditional and sessile serrated pathways based on the lesions involved in the oncogenic process, TSA and SSA/P respectively, and on different molecular features: BRAF or KRAS mutations, hypermethylation of $\mathrm{CpG}$ islands and MSI status (Figure 3) (Table 3) [29,33]. 


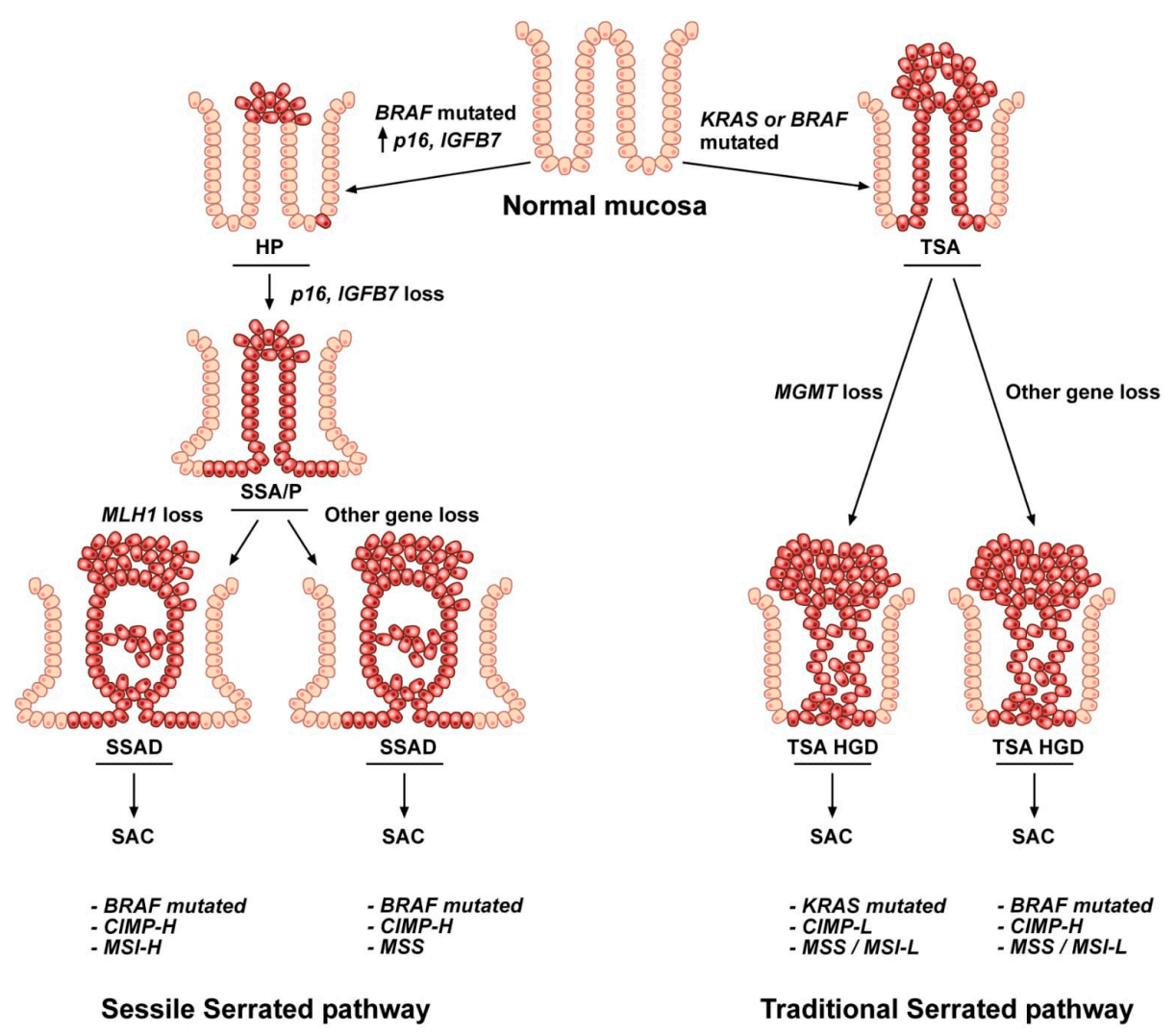

Figure 3. Representation of the two serrated pathways. The sequence leading to serrated Colorectal cancer (CRC) can occur in two different molecular pathways, the sessile and the traditional serrated routes. The tumorigenic process involves progressive accumulation of specific genetic and epigenetic hits affecting normal colon epithelial cells. In the sessile serrated pathway, the transformation of the normal mucosa begins with BRAF mutations, followed by $p 16$ and IGFBP7 promoter hypermethylation and the consequent progression toward serrated adenocarcinoma, mainly through MLH1 epigenetic alterations. In contrast, the traditional serrated pathway involves KRAS or BRAF mutations in normal colon cells which, together with MGMT or other gene methylation alterations, malignantly evolve toward traditional serrated adenoma (TSA) high-grade dysplasia and serrated adenocarcinoma (SAC).

Cancers arising through the traditional serrated pathway are predominantly localized in the distal colon and rectum. This pathway is the most controversial due to the molecular heterogeneity of the TSA lesions. The carcinogenetic mechanism that drives malignant transformation is KRAS or BRAF mutation in normal colon which consequently evolves toward a TSA lesion [29]. This pathway is characterized by a CIMP phenotype and is rarely associated with MLH1 hypermethylation (Table 3).

TSAs can progress toward dysplasia via two different molecular pathways [116]. Usually, TSA lesions which harbor KRAS mutations evolve toward conventional adenomatous dysplasia, while TSAs, which display BRAF mutations progress toward serrated dysplasia. Moreover, both dysplastic lesions can advance toward HGD due to aberrant promoter methylation of some genes. Among these latter, MGMT is usually associated with CIMP-L and MSS status (Figure 3). Finally, progression toward invasive carcinoma is driven by TP53 alterations [116].

The sessile serrated sequence begins in the proximal colon with a BRAF activating mutation that alters the MAPK-ERK pathway, inducing apoptosis arrest, colonocyte proliferation and $p 16$ and IGFBP7 over-expression (Figure 3) [30]. These changes determine the transformation of the normal mucosa into hyperplastic crypts, which then, due to $p 16$ and IGFBP7 promoter hypermethylation, evolve toward sessile serrated adenoma. In particular, HP lesions can stay dormant for a long time due to oncogene-induced senescence which inhibits the tumorigenic progress until an aberrant methylation of the $p 16$ and IGFBP7 promoters subverts this protective mechanism. P16 and IGFBP7 
are tumor suppressor genes: IGFBP7 is a direct target and mediator of $p 53$-dependent growth suppression, while $p 16$ encodes for the 16 protein that negatively regulates the $p 16 /$ cyclin-dependent kinase/retinoblastoma gene pathway involved in the control of the cell cycle $[117,118]$.

The oncogene-induced senescence process in CRC was first investigated in mice [119]. Then, the same mechanism has also been evidenced in human serrated polyps [118].

In human CRC, p16 methylation is usually linked to CIMP-H and MSI phenotype, and is particularly associated with SSA/Ps with respect to HP and TSA tumors. In fact, in addition to the $B R A F$-mediated alteration of the MAPK pathway, the inactivating hypermethylation of $p 16$ and IGFBP7 drives the progression of MVHP lesions toward sessile serrated adenomas/polyps, rendering the distinction between MVHP and SSA/P difficult to assess by endoscopy. Nevertheless, their distinction is clinically relevant due to their disparate outcome and relative interval of surveillance.

The next stage of polyp progression is the evolution of SSA/P lesion toward sessile serrated adenoma with high-grade dysplasia. This malignant evolution can be related either to MLH1 aberrant methylation with consequent amplification of microsatellites (MSI), usually representative of a good prognosis, or to MGMT hypermethylation with a stable number of microsatellite (MSS), associated with the poorest prognosis (Figure 3) (Table 3) [29,31].

The serrated pathway has two end results that differ in their clinical and prognostic features as well as in their methylome profile: (i) the serrated adenocarcinoma (SAC) or (ii) the sporadic colorectal carcinoma showing histological and molecular features of MSI-H (hmMSI-H) [31,120]. The CRC subtype hmMSI-H is associated with a dense immune infiltrate and shows a better prognosis than SACs [120].

\section{A Distinct Variant of Colorectal Cancer: Serrated Adenocarcinoma}

Serrated adenocarcinoma (SAC), which was first described by Jass and Smith in 1992, is histologically defined as an adenocarcinoma with serrated architecture and is one of the endpoints of the serrated pathway [121,122]. SAC accounts for $7.5-8.7 \%$ of all CRCs. It is located predominantly in the cecum and rectum, occurs particularly in females and has a worse prognosis than conventional carcinoma (CC) $[121,123]$. At the molecular level, SAC is a heterogeneous subtype. KRAS mutations, particularly the $12 \mathrm{G}>\mathrm{A}$ substitution, but predominantly $B R A F$ alterations, are frequent [124]. Although SACs mainly arise from TSA lesions and show a MSS phenotype, about $20 \%$ of them originate from SSA/Ps and are MSI.

Several studies have indicated PTCH1, HIF1 $\alpha$ and EPHB2 as SAC biomarkers [121,125-127]. PTCH1 expression is decreased, while HIF1 $\alpha$ is increased in SACs in comparison to CC, evidencing the molecular and histopathological differences between the two classes of CRC [125]. EPHB2, which encodes a tyrosine kinase receptor, is one of the most studied genes related to SAC [128]. EPHB2 is a well-established tumor suppressor gene whose downregulation often results from promoter hypermethylation [129]. The decreased expression of EPHB2 in serrated CRC may also potentiate the activation of the Notch signaling pathway which can further stimulate the expression of EPHB4 [128]. EPHB2 frameshift mutations are also frequent in MSI adenomas and carcinomas. Furthermore, a novel biomarker of SAC has recently been reported and consists of fascin-1 (FSCN1) whose over-expression has been associated with a progression from adenoma to carcinoma [127,130].

Methylome profiling has been performed in order to identify some genes that are differentially methylated between SAC and CC. DIO3 and FOXD2 appeared more methylated and less expressed at the mRNA level in SAC than in CC, thus revealing a SAC-associated epigenetic signature [131]. Differences in the molecular signature between SAC and hmMSI-H have also been studied. CD14 and HLADOA were the most significantly hypermethylated and underexpressed genes in hmMSI-H as compared to SAC [120]. In addition, gene expression profiling was carried out in order to clarify the role of the immune response between the two end results of the serrated pathway. As a result, a higher expression of ICAM1, an adhesion molecule involved in cellular immune responses, and a lower expression of CRCP and CXCL14 were identified in SAC versus hmMSI-H CRCs [132]. 
Additional studies will be necessary to further characterize SAC at a molecular level, not only to better clarify the malignant process of CRC progression but also to identify novel biomarkers for SAC targeted therapy.

\section{Superficially Serrated Adenoma}

A novel subtype of CRC, namely superficially serrated adenoma, has been recently described [133]. It is characterized by mixed morphological features of both conventional and serrated adenomas.

Superficially serrated adenomas show a median size of $5 \mathrm{~mm}$ and are preferentially located in the sigmoid colon or rectum. They appear like SSA/P polyps. However, in some cases, they can look like larger and flat lesions. At the molecular level, superficially serrated adenomas are homogeneous. KRAS mutation, RSPO fusion/overexpression and MLH1 loss are the most frequent alterations. BRAF, APC and GNAS mutations are present only in a few lesions. IHC analysis also revealed that superficially serrated adenomas show an overexpression of MYC, a nuclear accumulation of $\beta$-catenin and express Ki-67 preferentially in the upper half of the crypts.

Although identification of this novel type of polyp can contribute to better distinguish CRC subtypes, further studies will determine if superficially serrated adenoma can be subcategorized [133].

\section{MicroRNAs and Long Non-Coding RNAs in Serrated Colorectal Pathway}

MicroRNAs (miRNAs) and long non-coding RNAs (lncRNAs) are two important classes of RNAs involved in the regulation of gene expression [134]. Their altered expression has been described in CRCs, with distinct profiles observed between the conventional adenoma-carcinoma and serrated-carcinoma progression models [135-137]. Even if their role in cancer progression has not been elucidated yet, specific miRNA alterations have also been described in pre-cancerous lesions.

In this scenario, miR-31 is frequently overexpressed in sessile serrated adenomas suggesting an involvement in the progression of serrated lesions [138]. Interestingly, several studies showed an unique miRNA signature in different types of polyps. In this line, HPs and SSPs share a similar profile of miRNAs characterized by the down-regulation of a set of miRNAs, while normal colonic mucosa shows an up-regulation of miRNAs [139]. Another miRNA profiling in 109 patient biopsies allowed to discriminate between five different histopathologic groups [135]. In particular, the expression levels of miR-335, miR-222, and miR-214 were able to distinguish between non-serrated and serrated histology. Precisely, miR-335 was significantly overexpressed in non-serrated tissues compared to serrated lesions. Moreover, miR-222 and miR-214 were significantly downregulated in serrated polyps [135]. Finally, this study identified miR-125b and miR-320a as predictive biomarkers of the evolution toward CRC through the serrated pathway [135].

In a recent study, small RNA sequencing has been performed in 108 colon biopsies with different histology. Differential expression of miRNAs between tumor and healthy mucosal specimens was highlighted, and miRNAs specific of the serrated lesions were identified [136]. In particular, 23 miRNAs appeared differentially expressed between the serrated lesions and their paired healthy colon samples. Also, six miRNAs were differentially expressed between the serrated lesions and the hyperplastic polyps, with miR-31-5p being the most significantly modulated.

Similar results were observed for lncRNAs. Characterization of the lncRNA expression profiles in 888 CRC samples identified five different molecular clusters. These latter allowed to distinguish the conventional pathway from the serrated one [140]. Recently, the expression of 4898 lncRNAs has been monitored in 566 CRC samples and 282 lncRNAs illustrated the heterogeneity of CRCs [137]. Because the latter lncRNAs seem relevant for the development of CRC, their study may contribute to better understanding the origin of such tumor heterogeneity and facilitate the development of novel therapies [137].

Altogether, these findings show that non-coding RNAs may be useful to further discriminate the different subtypes of CRCs. 


\section{Dysbiosis of the Gut Microbiota: A New Biomarker?}

About 39 trillion microorganisms colonize the adult gut system, resulting in a biomass of $0.2 \mathrm{~kg}$ [141]. Human gut microbiota, whose composition varies across gut segments and between individuals, plays a multitude of functions, such as structural and metabolic roles or homeostasis maintenance of the intestinal immune system which constitutes a natural barrier to pathogen infection [142,143].

The plethora of bacterial species found in the human gastrointestinal tract belong to three phyla: Firmicutes (30-50\%) Bacteroidetes (20-40\%) and Actinobacteria (1-10\%) [144]. Environmental factors (infection, antibiotics, diet, lifestyle) can trigger an imbalance in the composition of the gut microbiota, known as dysbiosis. Dysbiosis has been associated with several diseases. In particular, it may initiate or promote carcinogenesis and influence anticancer immunosurveillance $[144,145]$. Thus, changes in microbiota composition are being evaluated as biomarkers for cancer diagnosis or prognosis [146,147].

The role of the gut microbiota in promoting or protecting against CRC has been studied. So far, these investigations have mainly been addressed to the conventional pathway, rather than the serrated one [148-151]. These analyzes particularly focused on the Gram-negative bacterium Fusobacterium nucleatum (F. nucleatum), which is rarely present in the gut of healthy people [152].

The overabundance of $F$. nucleatum has been associated with CRC progression [153,154]. In this way, F. nucleatum is involved in mucosal inflammation and promotes colorectal carcinogenesis by modulating E-cadherin/beta-catenin signaling. Its detection has been related to particular CRC subtypes [155]. Precisely, F. nucleatum has been linked with CIMP and MSI CRCs, thus encouraging its exploitation as a prognostic biomarker [156].

Regarding the serrated pathway, it has been evidenced that $F$. nucleatum is present in $56 \%$ of CRCs but appears less frequent in premalignant lesions. F. nucleatum was not associated with serrated precursor polyps, but was related to CIMP-H status and to large tumors, comforting its role in CRC progression [157]. The study also demonstrated an increasing density of F. nucleatum in SSA/Ps along the path between the sigmoid and the cecum. This observation was explained by the anatomy of the crypts in SSA/P. These crypts appeared rich with mucinous cells producing high mucus content which favors the survival of the bacteria.

Another study by Park et al. investigated the composition of the gut microbiota, including the presence of F. nucleatum, in patients with tubular adenoma and SSA/P [158]. The abundance of Fusobacteria was comparable between the two subtypes of adenomas but lower in comparison to the CRC group. A similar observation was reported by Ito et al. leading to the conclusion that Fusobacteria could contribute to both conventional and serrated pathways [157,158].

The Human Microbioma Projects 1 and 2 (HMP1 and HMP2) directed by the National Institute of Health (NIH, Bethesda, MD, USA) aim at collecting and comparing the human microbioma in healthy and diseased conditions [159]. Available data already highlighted the great variability of the microbioma across different physiopathological and environmental conditions. Future investigations should benefit to precision medicine.

Thus, new studies will be necessary to correlate the gut microbiome profile with the serrated adenoma-carcinoma pathway, and to identify novel biomarkers predictive of specific serrated lesions.

\section{Clinical Relevance of Molecular Alterations in the Serrated Colorectal Pathway}

Molecular heterogeneity among the subtypes of serrated colorectal tumors translates into a variety of clinical and prognostic implications $[19,160]$. Precisely, clinicopathological features have been related to the presence of BRAF mutations, MSI and CIMP in serrated CRCs. Interestingly, geographical location seems contributing to such molecular heterogeneity. For instance, in contrast to Eastern populations, Western populations show prevalent $B R A F$ mutated, CIMP, MSI CRCs [41].

The clinical role of MSI and CIMP has not been precisely described as opposed to BRAF and KRAS mutations. In general, $B R A F$ mutated, MSI and CIMP CRCs are more frequent in females and often localized in the proximal colon $[98,161]$. MSI CRCs present a good prognosis, while BRAF mutated and CIMP tumors are related to a later age-of-onset and to a poor clinical outcome $[38,65]$. Serrated BRAF 
mutated tumors have also been associated with heavy smoking [162]. The latter shows a negative prognostic outcome especially in the late stages of the disease, is associated with aggressive phenotypes, and seems to favor metastases in the peritoneum rather than in the liver or lungs $[163,164]$. Metastatic $B R A F$ mutated CRCs do not respond to anti-EGFR treatment, with or without chemotherapy [165]. Moreover, the presence of mutations in $B R A F$ has not demonstrated a predictive value for CRC therapy, so far [161]. The 5-year disease-free survival rate and overall survival appear poor in BRAF mutated patients even after lung/liver metastasectomy [161,163].

KRAS mutations are clinically heterogeneous as illustrated by their involvement in both traditional and serrated CRC pathways. KRAS mutated tumors have been correlated with high body weight. An association between KRAS mutated tumors and female gender has also been raised in the literature but remains controversial $[166,167]$. KRAS mutated tumors have been mainly explored in metastatic CRCs and associated with a poor outcome, notably a low 5-year disease-free survival, but are also associated with a short cancer-specific survival in stage I CRCs $[19,168]$.

CRCs harboring KRAS mutations also show resistance to anti-EGFR treatments and a negative response to 5-fluorouracil-based therapies [169]. In addition, KRAS mutations combined with MSS can increase the metastatic progression [170].

MSI is usually a molecular marker of a favorable prognosis independent of $B R A F, K R A S$, and CIMP status [19]. MSI is also associated with a lower frequency of late-stage diseases [171,172]. Patients with MSI cancers usually show a better prognosis and a longer disease-free survival with respect to MSS tumors [173]; they also benefit from chemotherapy [174]. However, patients with metastatic MSI CRCs having $B R A F$ mutations show a poor survival rate [175]. The MSI test is recommended for patients with stage II CRC in order to evaluate chemotherapy-based strategies [176]. In fact, 5-fluorouracil treatment has no positive effect on survival in patients with MSI CRCs [177].

MSS cancer, developing from TSA or SSA/Ps, is related to a poor prognosis [172,178]. Several studies reported that MSS CRCs, associated with BRAF mutations, show higher mortality and decreased overall survival with respect to both MSI/BRAF mutated and MSS/KRAS mutated cancers [179-181]. The good prognosis of MSI/BRAF mutated cancers may be related to the increased immune response in MSI tumor [182].

CIMP tumors are clinically heterogeneous. CIMP-L CRCs are associated with male gender, while CIMP-Hs show a female preponderance and tend to manifest at a later age and are associated with cigarette smoking [73]. The prognostic value of CIMP remains controversial especially for metastatic CRCs, perhaps because of their high molecular heterogeneity. In fact, although CIMP is mostly reported as a negative prognostic factor in CRC patients, several studies demonstrated that its prognostic value can be influenced by BRAF/KRAS and MSI status [183-185]. Among them, CIMP-H, MSS, BRAF mutated tumors show the worst prognosis of all CRCs $[19,22,186]$. The role of CIMP in tumor response to therapy is also controversial [187]. Nevertheless, CIMP-H stage III CRC patients can benefit from adjuvant irinotecan plus 5-fluorouracil chemotherapy [188].

Finally, epigenetic alterations can also influence clinical outcome of CRC patients. Hypermethylation in MLH1 or MGMT predicts good prognosis, whereas hypermethylation in $p 16$ or hypomethylation in the promoters of LINE-1 and IGF-2 are related to poor prognosis [19,113,189-191].

In conclusion, growing knowledge of the genetic mutations characterizing the different colorectal tumor subtypes, as well as their alterations at the epigenetic and signaling levels, is critical for better classifying CRCs, and therefore, for personalizing the treatments to reach superior efficacy (precision medicine).

\section{Conclusions}

This review is an excursus on the serrated pathway in colorectal carcinogenesis. It reports the new major genetic and epigenetic alterations, as well as the relevant emerging role of the gut microbiota, in serrated CRC. The molecular characterization of serrated polyps provides necessary information for their correct classification. Such classification allows to match the clinical signs and symptoms with 
the natural history of the disease; a critical consideration for adapting the care of the patient following diagnosis and during treatment follow-up.

Thus, we highlighted the need for combining a more precise set of molecular analyses together with histological assessments to better differentiate the serrated colorectal polyps.

In contrast to the conventional pathway, characterized by KRAS mutations, CIN, CIMP negative, and MSS, the progression from serrated polyp toward cancer seems driven and featured by alternative molecular imprints, with different prognostic significance.

Generally, there are two major serrated pathways, namely sessile and traditional, which differ in the lesions encountered along the oncogenic process: SSA/P and TSA, respectively. On the one hand, SSA/Ps are characterized by BRAF mutations, CIMP-H and MLH1 promoter methylation. On the other hand, TSA lesions harbor KRAS or BRAF mutations and can be MSS, CIMP-H or CIMP-L.

To shed light on the malignant adenoma-to-carcinoma progression, several transcriptomic and epigenomic studies have demonstrated that serrated polyps display a different molecular expression profile compared to the CC, thus identifying, for each serrated lesion, panels of markers for subtype-specific molecular signature, including microRNAs and lncRNAs. Nevertheless, the classification of serrated CRCs, and their respective diagnostic and prognostic values, still remain to be clarified. As underlined above, such clarification is rendered difficult by the high heterogeneity and the undiscovered molecular features of serrated lesions. Thus, the definition of new specific genetic and epigenetic features will be useful for supporting clinical-decision making and driving the choice of the most appropriate therapeutic approach.

Further studies will be necessary to confirm the emerging role of the gut microbiota, to establish a commonly accepted molecular classification of serrated lesions and to identify novel targets for treating CRC. The availability of advanced technologies able to investigate the molecular bases of human diseases with high resolution will further improve this field. Among them, omic analyses at a single cell level (genomics, transcriptomics, proteomics, metabolomics, etc.), applicable to dissociated tumors or circulating tumor cells, will likely contribute to identify new biomarkers. All these advances will facilitate personalized endoscopic, histologic and molecular surveillance of serrated CRC lesions and ultimately improve their clinical management.

Author Contributions: F.D.E.D.P.: conception and design, manuscript writing and editing; V.D. and M.C.M: manuscript writing and editing; F.S., J.P. and G.K.: editing and critical reading of the manuscript. All authors approved the final version of the manuscript.

Funding: F.S. is supported by Regional/MIUR funds (Satin, Ciro and Campania Biosience Project) to fight against the oncological group of disease. G.K. is supported by the Ligue contre le Cancer (équipe labellisée); Agence National de la Recherche (ANR)-Projets blancs; ANR under the frame of E-Rare-2, the ERA-Net for Research on Rare Diseases; Association pour la recherche sur le cancer (ARC); Cancéropôle Ile-de-France; Chancellerie des universités de Paris (Legs Poix), Fondation pour la Recherche Médicale (FRM); a donation by Elior; European Research Area Network on Cardiovascular Diseases (ERA-CVD, MINOTAUR); Gustave Roussy Odyssea, the European Union Horizon 2020 Project Oncobiome; Fondation Carrefour; High-end Foreign Expert Program in China (GDW20171100085), Institut National du Cancer (INCa); Inserm (HTE); Institut Universitaire de France; LeDucq Foundation; the LabEx Immuno-Oncology; the RHU Torino Lumière; the Seerave Foundation; the SIRIC Stratified Oncology Cell DNA Repair and Tumor Immune Elimination (SOCRATE); and the SIRIC Cancer Research and Personalized Medicine (CARPEM).

Acknowledgments: The authors would like to thank Giovanni D. De Palma for the endoscopic images and Mariano Giglio for critical suggestions.

Conflicts of Interest: The authors declare no conflict of interest.

\section{References}

1. Kuipers, E.J.; Grady, W.M.; Lieberman, D.; Seufferlein, T.; Sung, J.J.; Boelens, P.G.; van de Velde, C.J.H.; Watanabe, T. Colorectal cancer. Nat. Rev. Dis. Primer 2015, 1, 15065. [CrossRef] [PubMed]

2. Nguyen, H.T.; Nguyen, H.T.; Duong, H.-Q.; Duong, H.-Q. The molecular characteristics of colorectal cancer: Implications for diagnosis and therapy (Review). Oncol. Lett. 2018, 16, 9-18. [CrossRef] [PubMed]

3. Bogaert, J.; Prenen, H. Molecular genetics of colorectal cancer. Ann. Gastroenterol. 2014, 27, 9-14. [PubMed] 
4. Wong, K.; Xie, G. Updates on the Molecular Genetics of Colorectal Cancer. Colorectal Cancer Open Access 2017, 3. [CrossRef]

5. Kuipers, E.J.; Rösch, T.; Bretthauer, M. Colorectal cancer screening-optimizing current strategies and new directions. Nat. Rev. Clin. Oncol. 2013, 10, 130-142. [CrossRef] [PubMed]

6. Bardhan, K.; Liu, K. Epigenetics and colorectal cancer pathogenesis. Cancers 2013, 5, 676-713. [CrossRef] [PubMed]

7. Grady, W.M.; Carethers, J.M. Genomic and epigenetic instability in colorectal cancer pathogenesis. Gastroenterology 2008, 135, 1079-1099. [CrossRef]

8. Pancione, M.; Remo, A.; Colantuoni, V. Genetic and Epigenetic Events Generate Multiple Pathways in Colorectal Cancer Progression. Available online: https://www.hindawi.com/journals/pri/2012/509348/ (accessed on 27 February 2019).

9. Vogelstein, B.; Fearon, E.R.; Hamilton, S.R.; Kern, S.E.; Preisinger, A.C.; Leppert, M.; Nakamura, Y.; White, R.; Smits, A.M.; Bos, J.L. Genetic alterations during colorectal-tumor development. N. Engl. J. Med. 1988, 319, 525-532. [CrossRef]

10. Fearon, E.R.; Vogelstein, B. A genetic model for colorectal tumorigenesis. Cell 1990, 61, 759-767. [CrossRef]

11. Cho, K.R.; Vogelstein, B. Genetic alterations in the adenoma-carcinoma sequence. Cancer 1992, 70, $1727-1731$. [CrossRef]

12. Armaghany, T.; Wilson, J.D.; Chu, Q.; Mills, G. Genetic Alterations in Colorectal Cancer. GCR 2012, 5, $19-27$.

13. Geigl, J.B.; Obenauf, A.C.; Schwarzbraun, T.; Speicher, M.R. Defining "chromosomal instability". Trends Genet. 2008, 24, 64-69. [CrossRef]

14. Boland, C.R.; Goel, A. Microsatellite instability in colorectal cancer. Gastroenterology 2010, 138, $2073-2087$. [CrossRef]

15. Gupta, R.; Sinha, S.; Paul, R.N. The impact of microsatellite stability status in colorectal cancer. Curr. Probl. Cancer 2018, 42, 548-559. [CrossRef]

16. Pino, M.S.; Chung, D.C. The Chromosomal Instability Pathway in Colon Cancer. Gastroenterology 2010, 138, 2059-2072. [CrossRef]

17. O’Brien, M.J.; Yang, S.; Mack, C.; Xu, H.; Huang, C.S.; Mulcahy, E.; Amorosino, M.; Farraye, F.A. Comparison of microsatellite instability, CpG island methylation phenotype, BRAF and KRAS status in serrated polyps and traditional adenomas indicates separate pathways to distinct colorectal carcinoma end points. Am. J. Surg. Pathol. 2006, 30, 1491-1501. [CrossRef] [PubMed]

18. Gryfe, R.; Kim, H.; Hsieh, E.T.; Aronson, M.D.; Holowaty, E.J.; Bull, S.B.; Redston, M.; Gallinger, S. Tumor microsatellite instability and clinical outcome in young patients with colorectal cancer. N. Engl. J. Med. 2000, 342, 69-77. [CrossRef]

19. Murcia, O.; Juárez, M.; Hernández-Illán, E.; Egoavil, C.; Giner-Calabuig, M.; Rodríguez-Soler, M.; Jover, R. Serrated colorectal cancer: Molecular classification, prognosis, and response to chemotherapy. World J. Gastroenterol. 2016, 22, 3516-3530. [CrossRef]

20. Hegde, M.; Ferber, M.; Mao, R.; Samowitz, W.; Ganguly, A.; Working Group of the American College of Medical Genetics and Genomics (ACMG) Laboratory Quality Assurance Committee. ACMG technical standards and guidelines for genetic testing for inherited colorectal cancer (Lynch syndrome, familial adenomatous polyposis, and MYH-associated polyposis). Genet. Med. 2014, 16, 101-116. [CrossRef]

21. Jass, J.R. Classification of colorectal cancer based on correlation of clinical, morphological and molecular features. Histopathology 2007, 50, 113-130. [CrossRef]

22. Ogino, S.; Nosho, K.; Kirkner, G.J.; Kawasaki, T.; Meyerhardt, J.A.; Loda, M.; Giovannucci, E.L.; Fuchs, C.S. $\mathrm{CpG}$ island methylator phenotype, microsatellite instability, BRAF mutation and clinical outcome in colon cancer. Gut 2009, 58, 90-96. [CrossRef] [PubMed]

23. Yamagishi, H.; Kuroda, H.; Imai, Y.; Hiraishi, H. Molecular pathogenesis of sporadic colorectal cancers. Chin. J. Cancer 2016, 35. [CrossRef] [PubMed]

24. Lynch, H.T.; Snyder, C.L.; Shaw, T.G.; Heinen, C.D.; Hitchins, M.P. Milestones of Lynch syndrome: 1895-2015. Nat. Rev. Cancer 2015, 15, 181-194. [CrossRef] [PubMed]

25. Tutlewska, K.; Lubinski, J.; Kurzawski, G. Germline deletions in the EPCAM gene as a cause of Lynch syndrome-Literature review. Hered. Cancer Clin. Pract. 2013, 11, 9. [CrossRef] [PubMed] 
26. Bessa, X.; Ballesté, B.; Andreu, M.; Castells, A.; Bellosillo, B.; Balaguer, F.; Castellví-Bel, S.; Paya, A.; Jover, R.; Alenda, C.; et al. A prospective, multicenter, population-based study of BRAF mutational analysis for Lynch syndrome screening. Clin. Gastroenterol. Hepatol. 2008, 6, 206-214. [CrossRef] [PubMed]

27. Harvey, N.T.; Ruszkiewicz, A. Serrated neoplasia of the colorectum. World J. Gastroenterol. 2007, 13, 3792-3798. [CrossRef] [PubMed]

28. Rex, D.K.; Ahnen, D.J.; Baron, J.A.; Batts, K.P.; Burke, C.A.; Burt, R.W.; Goldblum, J.R.; Guillem, J.G.; Kahi, C.J.; Kalady, M.F.; et al. Serrated Lesions of the Colorectum: Review and Recommendations from an Expert Panel. Am. J. Gastroenterol. 2012, 107, 1315-1330. [CrossRef]

29. Patai, Á.V.; Molnár, B.; Tulassay, Z.; Sipos, F. Serrated pathway: Alternative route to colorectal cancer. World J. Gastroenterol. 2013, 19, 607-615. [CrossRef]

30. Leggett, B.; Whitehall, V. Role of the serrated pathway in colorectal cancer pathogenesis. Gastroenterology 2010, 138, 2088-2100. [CrossRef]

31. Bettington, M.; Walker, N.; Clouston, A.; Brown, I.; Leggett, B.; Whitehall, V. The serrated pathway to colorectal carcinoma: Current concepts and challenges. Histopathology 2013, 62, 367-386. [CrossRef]

32. Longacre, T.A.; Fenoglio-Preiser, C.M. Mixed hyperplastic adenomatous polyps/serrated adenomas. A distinct form of colorectal neoplasia. Am. J. Surg. Pathol. 1990, 14, 524-537. [CrossRef] [PubMed]

33. East, J.E.; Atkin, W.S.; Bateman, A.C.; Clark, S.K.; Dolwani, S.; Ket, S.N.; Leedham, S.J.; Phull, P.S.; Rutter, M.D.; Shepherd, N.A.; et al. British Society of Gastroenterology position statement on serrated polyps in the colon and rectum. Gut 2017, 66, 1181-1196. [CrossRef] [PubMed]

34. Pai, R.K.; Bettington, M.; Srivastava, A.; Rosty, C. An update on the morphology and molecular pathology of serrated colorectal polyps and associated carcinomas. Mod. Pathol. 2019, 1. [CrossRef] [PubMed]

35. Kahi, C.J. Screening Relevance of Sessile Serrated Polyps. Clin. Endosc. 2019, 52. [CrossRef] [PubMed]

36. Hamoudah, T.; Ma, K.; Esteban, M.; Hayat, W.; Berger, D.; Mahon, B.; Jakate, S.; Melson, J. Patients with small and diminutive proximal hyperplastic polyps have higher rates of synchronous advanced neoplasia compared with patients without serrated lesions. Gastrointest. Endosc. 2018, 87, 1518-1526. [CrossRef]

37. Mojarad, E.N.; Kuppen, P.J.; Aghdaei, H.A.; Zali, M.R. The CpG island methylator phenotype (CIMP) in colorectal cancer. Gastroenterol. Hepatol. Bed Bench 2013, 6, 120-128.

38. Barault, L.; Charon-Barra, C.; Jooste, V.; de la Vega, M.F.; Martin, L.; Roignot, P.; Rat, P.; Bouvier, A.-M.; Laurent-Puig, P.; Faivre, J.; et al. Hypermethylator phenotype in sporadic colon cancer: Study on a population-based series of 582 cases. Cancer Res. 2008, 68, 8541-8546. [CrossRef]

39. Borowsky, J.; Dumenil, T.; Bettington, M.; Pearson, S.-A.; Bond, C.; Fennell, L.; Liu, C.; McKeone, D.; Rosty, C.; Brown, I.; et al. The role of APC in WNT pathway activation in serrated neoplasia. Mod. Pathol. 2018, 31, 495-504. [CrossRef]

40. Guinney, J.; Dienstmann, R.; Wang, X.; de Reyniès, A.; Schlicker, A.; Soneson, C.; Marisa, L.; Roepman, P.; Nyamundanda, G.; Angelino, P.; et al. The Consensus Molecular Subtypes of Colorectal Cancer. Nat. Med. 2015, 21, 1350-1356. [CrossRef]

41. Bae, J.M.; Kim, J.H.; Kwak, Y.; Lee, D.-W.; Cha, Y.; Wen, X.; Lee, T.H.; Cho, N.-Y.; Jeong, S.-Y.; Park, K.J.; et al. Distinct clinical outcomes of two CIMP-positive colorectal cancer subtypes based on a revised CIMP classification system. Br. J. Cancer 2017, 116, 1012-1020. [CrossRef]

42. Fennell, L.; Dumenil, T.; Wockner, L.; Hartel, G.; Nones, K.; Bond, C.; Borowsky, J.; Liu, C.; McKeone, D.; Bowdler, L.; et al. Integrative Genome-Scale DNA Methylation Analysis of a Large and Unselected Cohort Reveals Five Distinct Subtypes of Colorectal Adenocarcinomas. Cell. Mol. Gastroenterol. Hepatol. 2019. [CrossRef] [PubMed]

43. Kahi, C.J.; Hewett, D.G.; Rex, D.K. Relationship of non-polypoid colorectal neoplasms to quality of colonoscopy. Gastrointest. Endosc. Clin. N. Am. 2010, 20, 407-415. [CrossRef] [PubMed]

44. Kahi, C.J.; Hewett, D.G.; Norton, D.L.; Eckert, G.J.; Rex, D.K. Prevalence and variable detection of proximal colon serrated polyps during screening colonoscopy. Clin. Gastroenterol. Hepatol. 2011, 9, 42-46. [CrossRef] [PubMed]

45. Torlakovic, E.; Skovlund, E.; Snover, D.C.; Torlakovic, G.; Nesland, J.M. Morphologic reappraisal of serrated colorectal polyps. Am. J. Surg. Pathol. 2003, 27, 65-81. [CrossRef] [PubMed]

46. Bosman, F.T.; Carneiro, F.; Hruban, R.H.; Theise, N.D. WHO Classification of Tumours of the Digestive System, 4th ed.; World Health Organization, International Agency for Research on Cancer (IARC): Lyon, France, 2010. 
47. Cassese, G.; Amendola, A.; Maione, F.; Giglio, M.C.; Pagano, G.; Milone, M.; Aprea, G.; Luglio, G.; De Palma, G.D. Serrated Lesions of the Colon-Rectum: A Focus on New Diagnostic Tools and Current Management. Gastroenterol. Res. Pract. 2019, 2019, 9179718. [CrossRef] [PubMed]

48. Aust, D.E.; Baretton, G.B.; Members of the Working Group GI-Pathology of the German Society of Pathology. Serrated polyps of the colon and rectum (hyperplastic polyps, sessile serrated adenomas, traditional serrated adenomas, and mixed polyps)-proposal for diagnostic criteria. Virchows Arch. Int. J. Pathol. 2010, 457, 291-297. [CrossRef] [PubMed]

49. Yamane, L.; Scapulatempo-Neto, C.; Reis, R.M.; Guimarães, D.P. Serrated pathway in colorectal carcinogenesis. World J. Gastroenterol. 2014, 20, 2634-2640. [CrossRef]

50. IJspeert, J.E.G.; Vermeulen, L.; Meijer, G.A.; Dekker, E. Serrated neoplasia-role in colorectal carcinogenesis and clinical implications. Nat. Rev. Gastroenterol. Hepatol. 2015, 12, 401-409. [CrossRef]

51. Murakami, T.; Sakamoto, N.; Nagahara, A. Endoscopic diagnosis of sessile serrated adenoma/polyp with and without dysplasia/carcinoma. World J. Gastroenterol. 2018, 24, 3250-3259. [CrossRef]

52. Torlakovic, E.; Snover, D.C. Serrated adenomatous polyposis in humans. Gastroenterology 1996, 110, 748-755. [CrossRef]

53. Yantiss, R.K.; Oh, K.Y.; Chen, Y.-T.; Redston, M.; Odze, R.D. Filiform serrated adenomas: A clinicopathologic and immunophenotypic study of 18 cases. Am. J. Surg. Pathol. 2007, 31, 1238-1245. [CrossRef] [PubMed]

54. Kalimuthu, S.N.; Chelliah, A.; Chetty, R. From traditional serrated adenoma to tubulovillous adenoma and beyond. World J. Gastrointest. Oncol. 2016, 8, 805-809. [CrossRef] [PubMed]

55. Kim, J.K.; Samaranayake, M.; Pradhan, S. Epigenetic mechanisms in mammals. Cell. Mol. Life Sci. CMLS 2009, 66, 596-612. [CrossRef] [PubMed]

56. Edwards, J.R.; Yarychkivska, O.; Boulard, M.; Bestor, T.H. DNA methylation and DNA methyltransferases. Epigenetics Chromatin 2017, 10. [CrossRef] [PubMed]

57. Robertson, K.D. DNA methylation and human disease. Nat. Rev. Genet. 2005, 6, 597-610. [CrossRef]

58. Yokoi, K.; Harada, H.; Yokota, K.; Ishii, S.; Tanaka, T.; Nishizawa, N.; Shimazu, M.; Kojo, K.; Miura, H.; Yamanashi, T.; et al. Epigenetic Status of CDO1 Gene May Reflect Chemosensitivity in Colon Cancer with Postoperative Adjuvant Chemotherapy. Ann. Surg. Oncol. 2019, 26, 406-414. [CrossRef]

59. Xue, W.; Wu, X.; Wang, F.; Han, P.; Cui, B. Genome-wide methylation analysis identifies novel prognostic methylation markers in colon adenocarcinoma. Biomed. Pharmacother. Biomed. Pharmacother. 2018, 108, 288-296. [CrossRef]

60. Kokelaar, R.F.; Jones, H.; Beynon, J.; Evans, M.E.; Harris, D.A. Meta-analysis of the prognostic value of CpG island methylator phenotype in rectal cancer. Int. J. Colorectal Dis. 2018, 33, 995-1000. [CrossRef]

61. Liu, C.; Bettington, M.L.; Walker, N.I.; Dwine, J.; Hartel, G.F.; Leggett, B.A.; Whitehall, V.L.J. CpG Island Methylation in Sessile Serrated Adenomas Increases With Age, Indicating Lower Risk of Malignancy in Young Patients. Gastroenterology 2018, 155, 1362-1365. [CrossRef]

62. Ogino, S.; Cantor, M.; Kawasaki, T.; Brahmandam, M.; Kirkner, G.J.; Weisenberger, D.J.; Campan, M.; Laird, P.W.; Loda, M.; Fuchs, C.S. CpG island methylator phenotype (CIMP) of colorectal cancer is best characterised by quantitative DNA methylation analysis and prospective cohort studies. Gut 2006, 55, 1000-1006. [CrossRef]

63. Noffsinger, A.E. Serrated polyps and colorectal cancer: New pathway to malignancy. Annu. Rev. Pathol. 2009, 4, 343-364. [CrossRef] [PubMed]

64. Advani, S.M.; Advani, P.; DeSantis, S.M.; Brown, D.; VonVille, H.M.; Lam, M.; Loree, J.M.; Sarshekeh, A.M.; Bressler, J.; Lopez, D.S.; et al. Clinical, Pathological, and Molecular Characteristics of CpG Island Methylator Phenotype in Colorectal Cancer: A Systematic Review and Meta-analysis. Transl. Oncol. 2018, 11, 1188-1201. [CrossRef]

65. Ogino, S.; Odze, R.D.; Kawasaki, T.; Brahmandam, M.; Kirkner, G.J.; Laird, P.W.; Loda, M.; Fuchs, C.S. Correlation of pathologic features with $\mathrm{CpG}$ island methylator phenotype (CIMP) by quantitative DNA methylation analysis in colorectal carcinoma. Am. J. Surg. Pathol. 2006, 30, 1175-1183. [CrossRef] [PubMed]

66. Shen, L.; Toyota, M.; Kondo, Y.; Lin, E.; Zhang, L.; Guo, Y.; Hernandez, N.S.; Chen, X.; Ahmed, S.; Konishi, K.; et al. Integrated genetic and epigenetic analysis identifies three different subclasses of colon cancer. Proc. Natl. Acad. Sci. USA 2007, 104, 18654-18659. [CrossRef] [PubMed] 
67. Weisenberger, D.J.; Levine, A.J.; Long, T.I.; Buchanan, D.D.; Walters, R.; Clendenning, M.; Rosty, C.; Joshi, A.D.; Stern, M.C.; LeMarchand, L.; et al. Association of the Colorectal CpG Island Methylator Phenotype with molecular features, risk factors and family history. Cancer Epidemiol. Biomark. Prev. 2015, 24, 512-519. [CrossRef] [PubMed]

68. Fang, M.; Ou, J.; Hutchinson, L.; Green, M.R. The BRAF oncoprotein functions through the transcriptional repressor MAFG to mediate the CpG Island Methylator phenotype. Mol. Cell 2014, 55, 904-915. [CrossRef] [PubMed]

69. Bond, C.E.; Liu, C.; Kawamata, F.; McKeone, D.M.; Fernando, W.; Jamieson, S.; Pearson, S.-A.; Kane, A.; Woods, S.L.; Lannagan, T.R.M.; et al. Oncogenic BRAF mutation induces DNA methylation changes in a murine model for human serrated colorectal neoplasia. Epigenetics 2018, 13, 40-48. [CrossRef]

70. Tao, Y.; Kang, B.; Petkovich, D.A.; Bhandari, Y.R.; In, J.; Stein-O’Brien, G.; Kong, X.; Xie, W.; Zachos, N.; Maegawa, S.; et al. Aging-like Spontaneous Epigenetic Silencing Facilitates Wnt Activation, Stemness, and BrafV600E-Induced Tumorigenesis. Cancer Cell 2019, 35, 315-328. [CrossRef]

71. Yagi, K.; Akagi, K.; Hayashi, H.; Nagae, G.; Tsuji, S.; Isagawa, T.; Midorikawa, Y.; Nishimura, Y.; Sakamoto, H.; Seto, Y.; et al. Three DNA methylation epigenotypes in human colorectal cancer. Clin. Cancer Res. 2010, 16, 21-33. [CrossRef]

72. Ogino, S.; Kawasaki, T.; Kirkner, G.J.; Kraft, P.; Loda, M.; Fuchs, C.S. Evaluation of markers for CpG island methylator phenotype (CIMP) in colorectal cancer by a large population-based sample. J. Mol. Diagn. 2007, 9, 305-314. [CrossRef]

73. Ogino, S.; Kawasaki, T.; Kirkner, G.J.; Loda, M.; Fuchs, C.S. CpG island methylator phenotype-low (CIMP-low) in colorectal cancer: Possible associations with male sex and KRAS mutations. J. Mol. Diagn. 2006, 8, 582-588. [CrossRef] [PubMed]

74. Hawkins, N.; Norrie, M.; Cheong, K.; Mokany, E.; Ku, S.-L.; Meagher, A.; O'Connor, T.; Ward, R. CpG island methylation in sporadic colorectal cancers and its relationship to microsatellite instability. Gastroenterology 2002, 122, 1376-1387. [CrossRef] [PubMed]

75. Toyota, M.; Ahuja, N.; Ohe-Toyota, M.; Herman, J.G.; Baylin, S.B.; Issa, J.P. CpG island methylator phenotype in colorectal cancer. Proc. Natl. Acad. Sci. USA 1999, 96, 8681-8686. [CrossRef] [PubMed]

76. Weisenberger, D.J.; Siegmund, K.D.; Campan, M.; Young, J.; Long, T.I.; Faasse, M.A.; Kang, G.H.; Widschwendter, M.; Weener, D.; Buchanan, D.; et al. CpG island methylator phenotype underlies sporadic microsatellite instability and is tightly associated with BRAF mutation in colorectal cancer. Nat. Genet. 2006, 38, 787-793. [CrossRef] [PubMed]

77. Ogino, S.; Kawasaki, T.; Kirkner, G.J.; Suemoto, Y.; Meyerhardt, J.A.; Fuchs, C.S. Molecular correlates with MGMT promoter methylation and silencing support CpG island methylator phenotype-low (CIMP-low) in colorectal cancer. Gut 2007, 56, 1564-1571. [CrossRef]

78. Parker, H.R.; Orjuela, S.; Martinho Oliveira, A.; Cereatti, F.; Sauter, M.; Heinrich, H.; Tanzi, G.; Weber, A.; Komminoth, P.; Vavricka, S.; et al. The proto CpG island methylator phenotype of sessile serrated adenomas/polyps. Epigenetics 2018, 13, 1088-1105. [CrossRef] [PubMed]

79. Imperiale, T.F.; Ransohoff, D.F.; Itzkowitz, S.H. Multitarget stool DNA testing for colorectal-cancer screening. N. Engl. J. Med. 2014, 371, 187-188. [CrossRef] [PubMed]

80. Kadiyska, T.; Nossikoff, A. Stool DNA methylation assays in colorectal cancer screening. World J. Gastroenterol. 2015, 21, 10057-10061. [CrossRef]

81. Hinoue, T.; Weisenberger, D.J.; Lange, C.P.E.; Shen, H.; Byun, H.-M.; Van Den Berg, D.; Malik, S.; Pan, F.; Noushmehr, H.; van Dijk, C.M.; et al. Genome-scale analysis of aberrant DNA methylation in colorectal cancer. Genome Res. 2012, 22, 271-282. [CrossRef]

82. Yang, S.; Farraye, F.A.; Mack, C.; Posnik, O.; O’Brien, M.J. BRAF and KRAS Mutations in hyperplastic polyps and serrated adenomas of the colorectum: Relationship to histology and CpG island methylation status. Am. J. Surg. Pathol. 2004, 28, 1452-1459. [CrossRef]

83. Spring, K.J.; Zhao, Z.Z.; Karamatic, R.; Walsh, M.D.; Whitehall, V.L.J.; Pike, T.; Simms, L.A.; Young, J.; James, M.; Montgomery, G.W.; et al. High Prevalence of Sessile Serrated Adenomas with BRAF Mutations: A Prospective Study of Patients Undergoing Colonoscopy. Gastroenterology 2006, 131, 1400-1407. [CrossRef] [PubMed]

84. Gibson, J.A.; Hahn, H.P.; Shahsafaei, A.; Odze, R.D. MUC expression in hyperplastic and serrated colonic polyps: Lack of specificity of MUC6. Am. J. Surg. Pathol. 2011, 35, 742-749. [CrossRef] [PubMed] 
85. Renaud, F.; Mariette, C.; Vincent, A.; Wacrenier, A.; Maunoury, V.; Leclerc, J.; Coppin, L.; Crépin, M.; Seuningen, I.V.; Leteurtre, E.; et al. The serrated neoplasia pathway of colorectal tumors: Identification of MUC5AC hypomethylation as an early marker of polyps with malignant potential. Int. J. Cancer 2016, 138, 1472-1481. [CrossRef] [PubMed]

86. Murakami, T.; Mitomi, H.; Saito, T.; Takahashi, M.; Sakamoto, N.; Fukui, N.; Yao, T.; Watanabe, S. Distinct $\mathrm{WNT} / \beta$-catenin signaling activation in the serrated neoplasia pathway and the adenoma-carcinoma sequence of the colorectum. Mod. Pathol. 2015, 28, 146-158. [CrossRef] [PubMed]

87. Ashktorab, H.; Delker, D.; Kanth, P.; Goel, A.; Carethers, J.M.; Brim, H. Molecular Characterization of sessile serrated adenoma/polyps from a large African American cohort. Gastroenterology 2019. [CrossRef]

88. Beggs, A.D.; Jones, A.; Shepherd, N.; Arnaout, A.; Finlayson, C.; Abulafi, A.M.; Morton, D.G.; Matthews, G.M.; Hodgson, S.V.; Tomlinson, I.P.M. Loss of Expression and Promoter Methylation of SLIT2 Are Associated with Sessile Serrated Adenoma Formation. PLoS Genet. 2013, 9. [CrossRef]

89. Caruso, M.; Moore, J.; Goodall, G.J.; Thomas, M.; Phillis, S.; Tyskin, A.; Cheetham, G.; Lerda, N.; Takahashi, H.; Ruszkiewicz, A. Over-expression of cathepsin E and trefoil factor 1 in sessile serrated adenomas of the colorectum identified by gene expression analysis. Virchows Arch. Int. J. Pathol. 2009, 454, 291-302. [CrossRef]

90. Gonzalo, D.H.; Lai, K.K.; Shadrach, B.; Goldblum, J.R.; Bennett, A.E.; Downs-Kelly, E.; Liu, X.; Henricks, W.; Patil, D.T.; Carver, P.; et al. Gene expression profiling of serrated polyps identifies annexin A10 as a marker of a sessile serrated adenoma/polyp. J. Pathol. 2013, 230, 420-429. [CrossRef]

91. Kanth, P.; Bronner, M.P.; Boucher, K.M.; Burt, R.W.; Neklason, D.W.; Hagedorn, C.H.; Delker, D.A. Gene Signature in Sessile Serrated Polyps Identifies Colon Cancer Subtype. Cancer Prev. Res. Phila. Pa 2016, 9, 456-465. [CrossRef]

92. Bae, J.M.; Kim, J.H.; Rhee, Y.-Y.; Cho, N.-Y.; Kim, T.-Y.; Kang, G.H. Annexin A10 expression in colorectal cancers with emphasis on the serrated neoplasia pathway. World J. Gastroenterol. 2015, 21, 9749-9757. [CrossRef]

93. Cui, M.; Awadallah, A.; Liu, W.; Zhou, L.; Xin, W. Loss of Hes1 Differentiates Sessile Serrated Adenoma/Polyp from Hyperplastic Polyp. Am. J. Surg. Pathol. 2016, 40, 113-119. [CrossRef] [PubMed]

94. Delker, D.A.; McGettigan, B.M.; Kanth, P.; Pop, S.; Neklason, D.W.; Bronner, M.P.; Burt, R.W.; Hagedorn, C.H. RNA Sequencing of Sessile Serrated Colon Polyps Identifies Differentially Expressed Genes and Immunohistochemical Markers. PLoS ONE 2014, 9. [CrossRef] [PubMed]

95. Rahmatallah, Y.; Khaidakov, M.; Lai, K.K.; Goyne, H.E.; Lamps, L.W.; Hagedorn, C.H.; Glazko, G. Platform-independent gene expression signature differentiates sessile serrated adenomas/polyps and hyperplastic polyps of the colon. BMC Med. Genomics 2017, 10. [CrossRef] [PubMed]

96. Mikhaleva, L.M.; Vandysheva, R.A.; Shakhpazyan, N.K.; Fedorov, E.D.; Biryukov, A.E.; Midiber, K.Y.; Pechnikova, V.V. [Comparative assessment of the expression of Muc 2, Muc 5AC, and Muc 6 in serrated neoplasms of the colon]. Arkh. Patol. 2019, 81, 10-17. [CrossRef] [PubMed]

97. Owens, S.R.; Chiosea, S.I.; Kuan, S.-F. Selective expression of gastric mucin MUC6 in colonic sessile serrated adenoma but not in hyperplastic polyp aids in morphological diagnosis of serrated polyps. Mod. Pathol. 2008, 21, 660-669. [CrossRef]

98. Travaglino, A.; D’Armiento, F.P.; Cassese, G.; Campanino, M.R.; Borrelli, G.; Pignatiello, S.; Luglio, G.; Maione, F.; De Palma, G.D.; D'Armiento, M. Clinico-pathological factors associated with BRAF-V600E mutation in colorectal serrated adenomas. Histopathology 2019. [CrossRef] [PubMed]

99. Murakami, T.; Akazawa, Y.; Yatagai, N.; Hiromoto, T.; Sasahara, N.; Saito, T.; Sakamoto, N.; Nagahara, A.; Yao, T. Molecular characterization of sessile serrated adenoma/polyps with dysplasia/carcinoma based on immunohistochemistry, next-generation sequencing, and microsatellite instability testing: A case series study. Diagn. Pathol. 2018, 13, 88. [CrossRef] [PubMed]

100. Yozu, M.; Kem, M.; Cenaj, O.; Mino-Kenudson, M.; Odze, R.D.; Misdraji, J. Loss of expression of MLH1 in non-dysplastic crypts is a harbinger of neoplastic progression in sessile serrated adenomas/polyps. Histopathology 2019. [CrossRef] [PubMed]

101. Hashimoto, T.; Yamashita, S.; Yoshida, H.; Taniguchi, H.; Ushijima, T.; Yamada, T.; Saito, Y.; Ochiai, A.; Sekine, S.; Hiraoka, N. WNT Pathway Gene Mutations Are Associated with the Presence of Dysplasia in Colorectal Sessile Serrated Adenoma/Polyps. Am. J. Surg. Pathol. 2017, 41, 1188-1197. [CrossRef] 
102. Bond, C.E.; McKeone, D.M.; Kalimutho, M.; Bettington, M.L.; Pearson, S.-A.; Dumenil, T.D.; Wockner, L.F.; Burge, M.; Leggett, B.A.; Whitehall, V.L.J. RNF43 and ZNRF3 are commonly altered in serrated pathway colorectal tumorigenesis. Oncotarget 2016, 7, 70589-70600. [CrossRef]

103. Koinuma, K.; Yamashita, Y.; Liu, W.; Hatanaka, H.; Kurashina, K.; Wada, T.; Takada, S.; Kaneda, R.; Choi, Y.L.; Fujiwara, S.-I.; et al. Epigenetic silencing of AXIN2 in colorectal carcinoma with microsatellite instability. Oncogene 2006, 25, 139-146. [CrossRef]

104. Liu, N.Q.; ter Huurne, M.; Nguyen, L.N.; Peng, T.; Wang, S.-Y.; Studd, J.B.; Joshi, O.; Ongen, H.; Bramsen, J.B.; Yan, J.; et al. The non-coding variant rs1800734 enhances DCLK3 expression through long-range interaction and promotes colorectal cancer progression. Nat. Commun. 2017, 8, 14418. [CrossRef]

105. Fennell, L.J.; Jamieson, S.; McKeone, D.; Corish, T.; Rohdmann, M.; Furner, T.; Bettington, M.; Liu, C.; Kawamata, F.; Bond, C.; et al. MLH1-93 G/a polymorphism is associated with MLH1 promoter methylation and protein loss in dysplastic sessile serrated adenomas with BRAFV600E mutation. BMC Cancer 2018, 18, 35. [CrossRef]

106. Torlakovic, E.E.; Gomez, J.D.; Driman, D.K.; Parfitt, J.R.; Wang, C.; Benerjee, T.; Snover, D.C. Sessile serrated adenoma (SSA) vs. traditional serrated adenoma (TSA). Am. J. Surg. Pathol. 2008, 32, 21-29. [CrossRef]

107. Bettington, M.L.; Walker, N.I.; Rosty, C.; Brown, I.S.; Clouston, A.D.; McKeone, D.M.; Pearson, S.-A.; Klein, K.; Leggett, B.A.; Whitehall, V.L.J. A clinicopathological and molecular analysis of 200 traditional serrated adenomas. Mod. Pathol. 2015, 28, 414-427. [CrossRef]

108. Whitehall, V.L.J.; Walsh, M.D.; Young, J.; Leggett, B.A.; Jass, J.R. Methylation of O-6-Methylguanine DNA Methyltransferase Characterizes a Subset of Colorectal Cancer with Low-level DNA Microsatellite Instability. Cancer Res. 2001, 61, 827-830.

109. Hashimoto, T.; Ogawa, R.; Yoshida, H.; Taniguchi, H.; Kojima, M.; Saito, Y.; Sekine, S. Acquisition of WNT Pathway Gene Alterations Coincides With the Transition From Precursor Polyps to Traditional Serrated Adenomas. Am. J. Surg. Pathol. 2019, 43, 132-139. [CrossRef]

110. Sekine, S.; Yamashita, S.; Tanabe, T.; Hashimoto, T.; Yoshida, H.; Taniguchi, H.; Kojima, M.; Shinmura, K.; Saito, Y.; Hiraoka, N.; et al. Frequent PTPRK-RSPO3 fusions and RNF43 mutations in colorectal traditional serrated adenoma. J. Pathol. 2016, 239, 133-138. [CrossRef]

111. Tsai, J.-H.; Jeng, Y.-M.; Yuan, C.-T.; Lin, Y.-L.; Cheng, M.-L.; Liau, J.-Y. Traditional Serrated Pathway-associated Colorectal Carcinoma: Morphologic Reappraisal of Serrated Morphology, Tumor Budding, and Identification of Frequent PTEN Alterations. Am. J. Surg. Pathol. 2019, 43. [CrossRef]

112. Aoki, H.; Yamamoto, E.; Takasawa, A.; Niinuma, T.; Yamano, H.-O.; Harada, T.; Matsushita, H.-O.; Yoshikawa, K.; Takagi, R.; Harada, E.; et al. Epigenetic silencing of SMOC1 in traditional serrated adenoma and colorectal cancer. Oncotarget 2017, 9, 4707-4721. [CrossRef]

113. Naito, T.; Nosho, K.; Ito, M.; Igarashi, H.; Mitsuhashi, K.; Yoshii, S.; Aoki, H.; Nomura, M.; Sukawa, Y.; Yamamoto, E.; et al. IGF2 differentially methylated region hypomethylation in relation to pathological and molecular features of serrated lesions. World J. Gastroenterol. 2014, 20, 10050-10061. [CrossRef]

114. Kerachian, M.A.; Kerachian, M. Long interspersed nucleotide element-1 (LINE-1) methylation in colorectal cancer. Clin. Chim. Acta Int. J. Clin. Chem. 2019, 488, 209-214. [CrossRef]

115. Nagai, Y.; Sunami, E.; Yamamoto, Y.; Hata, K.; Okada, S.; Murono, K.; Yasuda, K.; Otani, K.; Nishikawa, T.; Tanaka, T.; et al. LINE-1 hypomethylation status of circulating cell-free DNA in plasma as a biomarker for colorectal cancer. Oncotarget 2017, 8, 11906-11916. [CrossRef]

116. Tsai, J.-H.; Liau, J.-Y.; Lin, Y.-L.; Lin, L.-I.; Cheng, Y.-C.; Cheng, M.-L.; Jeng, Y.-M. Traditional serrated adenoma has two pathways of neoplastic progression that are distinct from the sessile serrated pathway of colorectal carcinogenesis. Mod. Pathol. 2014, 27, 1375-1385. [CrossRef]

117. Wajapeyee, N.; Serra, R.W.; Zhu, X.; Mahalingam, M.; Green, M.R. Role for IGFBP7 in senescence induction by BRAF. Cell 2010, 141, 746-747. [CrossRef]

118. Kriegl, L.; Neumann, J.; Vieth, M.; Greten, F.R.; Reu, S.; Jung, A.; Kirchner, T. Up and downregulation of p16(Ink4a) expression in BRAF-mutated polyps/adenomas indicates a senescence barrier in the serrated route to colon cancer. Mod. Pathol. 2011, 24, 1015-1022. [CrossRef]

119. Carragher, L.A.S.; Snell, K.R.; Giblett, S.M.; Aldridge, V.S.S.; Patel, B.; Cook, S.J.; Winton, D.J.; Marais, R.; Pritchard, C.A. V600EBraf induces gastrointestinal crypt senescence and promotes tumour progression through enhanced CpG methylation of p16INK4a. EMBO Mol. Med. 2010, 2, 458-471. [CrossRef] 
120. García-Solano, J.; Turpin, M.C.; Torres-Moreno, D.; Huertas-López, F.; Tuomisto, A.; Mäkinen, M.J.; Conesa, A.; Conesa-Zamora, P. Two histologically colorectal carcinomas subsets from the serrated pathway show different methylome signatures and diagnostic biomarkers. Clin. Epigenetics 2018, 10, 141. [CrossRef]

121. Mäkinen, M.J. Colorectal serrated adenocarcinoma. Histopathology 2007, 50, 131-150. [CrossRef]

122. Jass, J.R.; Smith, M. Sialic acid and epithelial differentiation in colorectal polyps and cancer-A morphological, mucin and lectin histochemical study. Pathology (Phila.) 1992, 24, 233-242. [CrossRef]

123. García-Solano, J.; Pérez-Guillermo, M.; Conesa-Zamora, P.; Acosta-Ortega, J.; Trujillo-Santos, J.; Cerezuela-Fuentes, P.; Mäkinen, M.J. Clinicopathologic study of 85 colorectal serrated adenocarcinomas: Further insights into the full recognition of a new subset of colorectal carcinoma. Hum. Pathol. 2010, 41, 1359-1368. [CrossRef]

124. Stefanius, K.; Ylitalo, L.; Tuomisto, A.; Kuivila, R.; Kantola, T.; Sirniö, P.; Karttunen, T.J.; Mäkinen, M.J. Frequent mutations of KRAS in addition to BRAF in colorectal serrated adenocarcinoma. Histopathology 2011, 58, 679-692. [CrossRef]

125. Laiho, P.; Kokko, A.; Vanharanta, S.; Salovaara, R.; Sammalkorpi, H.; Järvinen, H.; Mecklin, J.-P.; Karttunen, T.J.; Tuppurainen, K.; Davalos, V.; et al. Serrated carcinomas form a subclass of colorectal cancer with distinct molecular basis. Oncogene 2007, 26, 312-320. [CrossRef]

126. Tuomisto, A.; García-Solano, J.; Sirniö, P.; Väyrynen, J.; Pérez-Guillermo, M.; Mäkinen, M.J.; Conesa-Zamora, P. HIF-1 $\alpha$ expression and high microvessel density are characteristic features in serrated colorectal cancer. Virchows Arch. Int. J. Pathol. 2016, 469, 395-404. [CrossRef]

127. García-Solano, J.; García-Solano, M.E.; Torres-Moreno, D.; Carbonell, P.; Trujillo-Santos, J.; Pérez-Guillermo, M.; Conesa-Zamora, P. Biomarkers for the identification of precursor polyps of colorectal serrated adenocarcinomas. Cell. Oncol. Dordr. 2016, 39, 243-252. [CrossRef]

128. Lian, H.; Jia, X.; Shi, N.; Xie, S.; Wang, J.; Wang, W.; Ma, F.; Liu, H.; Wang, A.; Cheng, X.; et al. Notch signaling promotes serrated neoplasia pathway in colorectal cancer through epigenetic modification of EPHB2 and EPHB4. Cancer Manag. Res. 2018, 10, 6129-6141. [CrossRef]

129. Alazzouzi, H.; Davalos, V.; Kokko, A.; Domingo, E.; Woerner, S.M.; Wilson, A.J.; Konrad, L.; Laiho, P.; Espín, E.; Armengol, M.; et al. Mechanisms of inactivation of the receptor tyrosine kinase EPHB2 in colorectal tumors. Cancer Res. 2005, 65, 10170-10173. [CrossRef]

130. Conesa-Zamora, P.; García-Solano, J.; García-García, F.; Turpin, M.D.C.; Trujillo-Santos, J.; Torres-Moreno, D.; Oviedo-Ramírez, I.; Carbonell-Muñoz, R.; Muñoz-Delgado, E.; Rodriguez-Braun, E.; et al. Expression profiling shows differential molecular pathways and provides potential new diagnostic biomarkers for colorectal serrated adenocarcinoma. Int. J. Cancer 2013, 132, 297-307. [CrossRef]

131. Conesa-Zamora, P.; García-Solano, J.; Turpin, M.D.C.; Sebastián-León, P.; Torres-Moreno, D.; Estrada, E.; Tuomisto, A.; Wilce, J.; Mäkinen, M.J.; Pérez-Guillermo, M.; et al. Methylome profiling reveals functions and genes which are differentially methylated in serrated compared to conventional colorectal carcinoma. Clin. Epigenetics 2015, 7, 101. [CrossRef]

132. García-Solano, J.; Del Carmen Turpin, M.; García-García, F.; Carbonell-Muñoz, R.; Torres-Moreno, D.; Conesa, A.; Conesa-Zamora, P. Differences in gene expression profiling and biomarkers between histological colorectal carcinoma subsets from the serrated pathway. Histopathology 2019. [CrossRef]

133. Hashimoto, T.; Tanaka, Y.; Ogawa, R.; Mori, T.; Yoshida, H.; Taniguchi, H.; Hiraoka, N.; Kojima, M.; Oono, Y.; Saito, Y.; et al. Superficially serrated adenoma: A proposal for a novel subtype of colorectal serrated lesion. Mod. Pathol. 2018, 31, 1588-1598. [CrossRef]

134. Anastasiadou, E.; Jacob, L.S.; Slack, F.J. Non-coding RNA networks in cancer. Nat. Rev. Cancer 2018, 18, 5-18. [CrossRef]

135. Tsikitis, V.L.; Potter, A.; Mori, M.; Buckmeier, J.A.; Preece, C.R.; Harrington, C.A.; Bartley, A.N.; Bhattacharyya, A.K.; Hamilton, S.R.; Lance, M.P.; et al. MicroRNA Signatures of Colonic Polyps on Screening and Histology. Cancer Prev. Res. Phila. Pa 2016, 9, 942-949. [CrossRef]

136. Kanth, P.; Hazel, M.W.; Boucher, K.M.; Yang, Z.; Wang, L.; Bronner, M.P.; Boylan, K.E.; Burt, R.W.; Westover, M.; Neklason, D.W.; et al. Small RNA sequencing of sessile serrated polyps identifies microRNA profile associated with colon cancer. Genes. Chromosomes Cancer 2019, 58, 23-33. [CrossRef]

137. James de Bony, E.; Bizet, M.; Van Grembergen, O.; Hassabi, B.; Calonne, E.; Putmans, P.; Bontempi, G.; Fuks, F. Comprehensive identification of long noncoding RNAs in colorectal cancer. Oncotarget 2018, 9, 27605-27629. 
138. Aoki, H.; Nosho, K.; Igarashi, H.; Ito, M.; Mitsuhashi, K.; Naito, T.; Yamamoto, E.; Tanuma, T.; Nomura, M.; Maguchi, H.; et al. MicroRNA-31 expression in colorectal serrated pathway progression. World J. Gastroenterol. 2014, 20, 12346-12349. [CrossRef]

139. Slattery, M.L.; Herrick, J.S.; Wolff, R.K.; Mullany, L.E.; Stevens, J.R.; Samowitz, W. The miRNA Landscape of Colorectal Polyps. Genes. Chromosomes Cancer 2017, 56, 347-353. [CrossRef]

140. Chen, H.; Xu, J.; Hong, J.; Tang, R.; Zhang, X.; Fang, J.-Y. Long noncoding RNA profiles identify five distinct molecular subtypes of colorectal cancer with clinical relevance. Mol. Oncol. 2014, 8, 1393-1403. [CrossRef]

141. Sender, R.; Fuchs, S.; Milo, R. Are We Really Vastly Outnumbered? Revisiting the Ratio of Bacterial to Host Cells in Humans. Cell 2016, 164, 337-340. [CrossRef]

142. D'Argenio, V.; Salvatore, F. The role of the gut microbiome in the healthy adult status. Clin. Chim. Acta Int. J. Clin. Chem. 2015, 451, 97-102. [CrossRef]

143. Cani, P.D. Human gut microbiome: Hopes, threats and promises. Gut 2018, 67, 1716-1725. [CrossRef]

144. Gagnière, J.; Raisch, J.; Veziant, J.; Barnich, N.; Bonnet, R.; Buc, E.; Bringer, M.-A.; Pezet, D.; Bonnet, M. Gut microbiota imbalance and colorectal cancer. World J. Gastroenterol. 2016, 22, 501-518. [CrossRef]

145. Zitvogel, L.; Ayyoub, M.; Routy, B.; Kroemer, G. Microbiome and Anticancer Immunosurveillance. Cell 2016, 165, 276-287. [CrossRef]

146. Kroemer, G.; Zitvogel, L. Cancer immunotherapy in 2017: The breakthrough of the microbiota. Nat. Rev. Immunol. 2018, 18, 87-88. [CrossRef]

147. Mangifesta, M.; Mancabelli, L.; Milani, C.; Gaiani, F.; de'Angelis, N.; de'Angelis, G.L.; van Sinderen, D.; Ventura, M.; Turroni, F. Mucosal microbiota of intestinal polyps reveals putative biomarkers of colorectal cancer. Sci. Rep. 2018, 8, 13974. [CrossRef]

148. Jahani-Sherafat, S.; Alebouyeh, M.; Moghim, S.; Ahmadi Amoli, H.; Ghasemian-Safaei, H. Role of gut microbiota in the pathogenesis of colorectal cancer; a review article. Gastroenterol. Hepatol. Bed Bench 2018, 11, 101-109.

149. Chen, G.Y. The Role of the Gut Microbiome in Colorectal Cancer. Clin. Colon Rectal Surg. 2018, 31, $192-198$. [CrossRef]

150. Peters, B.A.; Dominianni, C.; Shapiro, J.A.; Church, T.R.; Wu, J.; Miller, G.; Yuen, E.; Freiman, H.; Lustbader, I.; Salik, J.; et al. The gut microbiota in conventional and serrated precursors of colorectal cancer. Microbiome 2016, 4. [CrossRef]

151. Yoon, H.; Kim, N.; Park, J.H.; Kim, Y.S.; Lee, J.; Kim, H.W.; Choi, Y.J.; Shin, C.M.; Park, Y.S.; Lee, D.H.; et al. Comparisons of Gut Microbiota Among Healthy Control, Patients with Conventional Adenoma, Sessile Serrated Adenoma, and Colorectal Cancer. J. Cancer Prev. 2017, 22, 108-114. [CrossRef]

152. Holt, R.A.; Cochrane, K. Tumor Potentiating Mechanisms of Fusobacterium nucleatum, A Multifaceted Microbe. Gastroenterology 2017, 152, 694-696. [CrossRef]

153. Shang, F.-M.; Liu, H.-L. Fusobacterium nucleatum and colorectal cancer: A review. World J. Gastrointest. Oncol. 2018, 10, 71-81. [CrossRef]

154. Bullman, S.; Pedamallu, C.S.; Sicinska, E.; Clancy, T.E.; Zhang, X.; Cai, D.; Neuberg, D.; Huang, K.; Guevara, F.; Nelson, T.; et al. Analysis of Fusobacterium persistence and antibiotic response in colorectal cancer. Science 2017, 358, 1443-1448. [CrossRef]

155. Ma, C.-T.; Luo, H.-S.; Gao, F.; Tang, Q.-C.; Chen, W. Fusobacterium nucleatum promotes the progression of colorectal cancer by interacting with E-cadherin. Oncol. Lett. 2018, 16, 2606-2612. [CrossRef]

156. Lee, D.-W.; Han, S.-W.; Kang, J.-K.; Bae, J.M.; Kim, H.-P.; Won, J.-K.; Jeong, S.-Y.; Park, K.J.; Kang, G.H.; Kim, T.-Y. Association Between Fusobacterium nucleatum, Pathway Mutation, and Patient Prognosis in Colorectal Cancer. Ann. Surg. Oncol. 2018, 25, 3389-3395. [CrossRef]

157. Ito, M.; Kanno, S.; Nosho, K.; Sukawa, Y.; Mitsuhashi, K.; Kurihara, H.; Igarashi, H.; Takahashi, T.; Tachibana, M.; Takahashi, H.; et al. Association of Fusobacterium nucleatum with clinical and molecular features in colorectal serrated pathway. Int. J. Cancer 2015, 137, 1258-1268. [CrossRef]

158. Park, C.H.; Han, D.S.; Oh, Y.-H.; Lee, A.; Lee, Y.; Eun, C.S. Role of Fusobacteria in the serrated pathway of colorectal carcinogenesis. Sci. Rep. 2016, 6, 25271. [CrossRef]

159. The Integrative HMP (iHMP) Research Network Consortium. The Integrative Human Microbiome Project. Nature 2019, 569, 641-648. [CrossRef]

160. O'Connell, B.M.; Crockett, S.D. The clinical impact of serrated colorectal polyps. Clin. Epidemiol. 2017, 9, 113-125. [CrossRef] 
161. Bond, C.E.; Whitehall, V.L.J. How the BRAF V600E Mutation Defines a Distinct Subgroup of Colorectal Cancer: Molecular and Clinical Implications. Gastroenterol. Res. Pract. 2018, 2018. [CrossRef]

162. Rozek, L.S.; Herron, C.M.; Greenson, J.K.; Moreno, V.; Capella, G.; Rennert, G.; Gruber, S.B. Smoking, gender, and ethnicity predict somatic BRAF mutations in colorectal cancer. Cancer Epidemiol. Biomark. Prev. 2010, 19, 838-843. [CrossRef]

163. Yaeger, R.; Cercek, A.; Chou, J.F.; Sylvester, B.E.; Kemeny, N.E.; Hechtman, J.F.; Ladanyi, M.; Rosen, N.; Weiser, M.R.; Capanu, M.; et al. BRAF mutation predicts for poor outcomes after metastasectomy in patients with metastatic colorectal cancer. Cancer 2014, 120, 2316-2324. [CrossRef]

164. Prasanna, T.; Karapetis, C.S.; Roder, D.; Tie, J.; Padbury, R.; Price, T.; Wong, R.; Shapiro, J.; Nott, L.; Lee, M.; et al. The survival outcome of patients with metastatic colorectal cancer based on the site of metastases and the impact of molecular markers and site of primary cancer on metastatic pattern. Acta Oncol. Stockh. Swed. 2018, 57, 1438-1444. [CrossRef]

165. Ursem, C.; Atreya, C.E.; Van Loon, K. Emerging treatment options for BRAF-mutant colorectal cancer. Gastrointest. Cancer Targets Ther. 2018, 8, 13-23. [CrossRef]

166. Brändstedt, J.; Wangefjord, S.; Nodin, B.; Eberhard, J.; Sundström, M.; Manjer, J.; Jirström, K. Associations of anthropometric factors with KRAS and BRAF mutation status of primary colorectal cancer in men and women: A cohort study. PLoS ONE 2014, 9, e98964.

167. Gil Ferreira, C.; Aran, V.; Zalcberg-Renault, I.; Victorino, A.P.; Salem, J.H.; Bonamino, M.H.; Vieira, F.M.; Zalis, M. KRAS mutations: Variable incidences in a Brazilian cohort of 8234 metastatic colorectal cancer patients. BMC Gastroenterol. 2014, 14. [CrossRef]

168. Reggiani Bonetti, L.; Barresi, V.; Maiorana, A.; Manfredini, S.; Caprera, C.; Bettelli, S. Clinical Impact and Prognostic Role of KRAS/BRAF/PIK3CA Mutations in Stage I Colorectal Cancer. Dis. Markers 2018, 2018. [CrossRef]

169. Therkildsen, C.; Bergmann, T.K.; Henrichsen-Schnack, T.; Ladelund, S.; Nilbert, M. The predictive value of KRAS, NRAS, BRAF, PIK3CA and PTEN for anti-EGFR treatment in metastatic colorectal cancer: A systematic review and meta-analysis. Acta Oncol. Stockh. Swed. 2014, 53, 852-864. [CrossRef]

170. Nash, G.M.; Gimbel, M.; Cohen, A.M.; Zeng, Z.-S.; Ndubuisi, M.I.; Nathanson, D.R.; Ott, J.; Barany, F.; Paty, P.B. KRAS mutation and microsatellite instability: Two genetic markers of early tumor development that influence the prognosis of colorectal cancer. Ann. Surg. Oncol. 2010, 17, 416-424. [CrossRef]

171. Mohan, H.M.; Ryan, E.; Balasubramanian, I.; Kennelly, R.; Geraghty, R.; Sclafani, F.; Fennelly, D.; McDermott, R.; Ryan, E.J.; O'Donoghue, D.; et al. Microsatellite instability is associated with reduced disease specific survival in stage III colon cancer. Eur. J. Surg. Oncol. 2016, 42, 1680-1686. [CrossRef]

172. Popat, S.; Hubner, R.; Houlston, R.S. Systematic review of microsatellite instability and colorectal cancer prognosis. J. Clin. Oncol. 2005, 23, 609-618. [CrossRef]

173. Kim, C.G.; Ahn, J.B.; Jung, M.; Beom, S.H.; Kim, C.; Kim, J.H.; Heo, S.J.; Park, H.S.; Kim, J.H.; Kim, N.K.; et al. Effects of microsatellite instability on recurrence patterns and outcomes in colorectal cancers. Br. J. Cancer 2016, 115, 25-33. [CrossRef]

174. Inamura, K. Colorectal Cancers: An Update on Their Molecular Pathology. Cancers 2018, 10, 26. [CrossRef]

175. Venderbosch, S.; Nagtegaal, I.D.; Maughan, T.S.; Smith, C.G.; Cheadle, J.P.; Fisher, D.; Kaplan, R.; Quirke, P.; Seymour, M.T.; Richman, S.D.; et al. Mismatch repair status and BRAF mutation status in metastatic colorectal cancer patients: A pooled analysis of the CAIRO, CAIRO2, COIN, and FOCUS studies. Clin. Cancer Res. 2014, 20, 5322-5330. [CrossRef]

176. Benson, A.B.; Venook, A.P.; Cederquist, L.; Chan, E.; Chen, Y.-J.; Cooper, H.S.; Deming, D.; Engstrom, P.F.; Enzinger, P.C.; Fichera, A.; et al. Colon Cancer, Version 1.2017, NCCN Clinical Practice Guidelines in Oncology. J. Natl. Compr. Cancer Netw. 2017, 15, 370-398. [CrossRef]

177. Webber, E.M.; Kauffman, T.L.; O'Connor, E.; Goddard, K.A.B. Systematic review of the predictive effect of MSI status in colorectal cancer patients undergoing 5FU-based chemotherapy. BMC Cancer 2015, 15, 156. [CrossRef]

178. Kang, S.; Na, Y.; Joung, S.Y.; Lee, S.I.; Oh, S.C.; Min, B.W. The significance of microsatellite instability in colorectal cancer after controlling for clinicopathological factors. Medicine (Baltimore) 2018, 97. [CrossRef]

179. Yang, Y.; Wang, D.; Jin, L.; Wu, G.; Bai, Z.; Wang, J.; Yao, H.; Zhang, Z. Prognostic value of the combination of microsatellite instability and BRAF mutation in colorectal cancer. Cancer Manag. Res. 2018, 10, 3911-3929. [CrossRef] 
180. Seppälä, T.T.; Böhm, J.P.; Friman, M.; Lahtinen, L.; Väyrynen, V.M.J.; Liipo, T.K.E.; Ristimäki, A.P.; Kairaluoma, M.V.J.; Kellokumpu, I.H.; Kuopio, T.H.I.; et al. Combination of microsatellite instability and BRAF mutation status for subtyping colorectal cancer. Br. J. Cancer 2015, 112, 1966-1975. [CrossRef]

181. Samowitz, W.S.; Sweeney, C.; Herrick, J.; Albertsen, H.; Levin, T.R.; Murtaugh, M.A.; Wolff, R.K.; Slattery, M.L. Poor survival associated with the BRAF V600E mutation in microsatellite-stable colon cancers. Cancer Res. 2005, 65, 6063-6069. [CrossRef]

182. Diaz, L.A.; Le, D.T. PD-1 Blockade in Tumors with Mismatch-Repair Deficiency. N. Engl. J. Med. 2015, 373, 1979.

183. Lee, S.; Cho, N.-Y.; Choi, M.; Yoo, E.J.; Kim, J.-H.; Kang, G.H. Clinicopathological features of CpG island methylator phenotype-positive colorectal cancer and its adverse prognosis in relation to KRAS/BRAF mutation. Pathol. Int. 2008, 58, 104-113. [CrossRef]

184. Dahlin, A.M.; Palmqvist, R.; Henriksson, M.L.; Jacobsson, M.; Eklöf, V.; Rutegård, J.; Oberg, A.; Van Guelpen, B.R. The role of the CpG island methylator phenotype in colorectal cancer prognosis depends on microsatellite instability screening status. Clin. Cancer Res. 2010, 16, 1845-1855. [CrossRef]

185. Ward, R.L.; Cheong, K.; Ku, S.-L.; Meagher, A.; O'Connor, T.; Hawkins, N.J. Adverse prognostic effect of methylation in colorectal cancer is reversed by microsatellite instability. J. Clin. Oncol. 2003, 21, 3729-3736. [CrossRef]

186. Murcia, O.; Juárez, M.; Rodríguez-Soler, M.; Hernández-Illán, E.; Giner-Calabuig, M.; Alustiza, M.; Egoavil, C.; Castillejo, A.; Alenda, C.; Barberá, V.; et al. Colorectal cancer molecular classification using BRAF, KRAS, microsatellite instability and CIMP status: Prognostic implications and response to chemotherapy. PLoS ONE 2018, 13. [CrossRef]

187. Juo, Y.Y.; Johnston, F.M.; Zhang, D.Y.; Juo, H.H.; Wang, H.; Pappou, E.P.; Yu, T.; Easwaran, H.; Baylin, S.; van Engeland, M.; et al. Prognostic value of $\mathrm{CpG}$ island methylator phenotype among colorectal cancer patients: A systematic review and meta-analysis. Ann. Oncol. 2014, 25, 2314-2327. [CrossRef]

188. Shiovitz, S.; Bertagnolli, M.M.; Renfro, L.A.; Nam, E.; Foster, N.R.; Dzieciatkowski, S.; Luo, Y.; Lao, V.V.; Monnat, R.J.; Emond, M.J.; et al. CpG island methylator phenotype is associated with response to adjuvant irinotecan-based therapy for stage III colon cancer. Gastroenterology 2014, 147, 637-645. [CrossRef]

189. Vodolazhsky, D.I.; Timoshkina, N.N.; Panina, S.B. LINE-1 hypomethylation in colon cancer. J. Clin. Oncol. 2018, 36, 588. [CrossRef]

190. Zhou, N.; Gu, Q. Prognostic and clinicopathological value of p16 protein aberrant expression in colorectal cancer. Medicine (Baltimore) 2018, 97. [CrossRef]

191. Fu, T.; Liu, Y.; Li, K.; Wan, W.; Pappou, E.P.; Iacobuzio-Donahue, C.A.; Kerner, Z.; Baylin, S.B.; Wolfgang, C.L.; Ahuja, N. Tumors with unmethylated MLH1 and the CpG island methylator phenotype are associated with a poor prognosis in stage II colorectal cancer patients. Oncotarget 2016, 7, 86480-86489. [CrossRef] 